Chapter 15

\title{
Multiple Myeloma in Horses, Dogs and Cats: A Comparative Review Focused on Clinical Signs and Pathogenesis
}

\author{
A. Muñoz, C. Riber, K. Satué, P. Trigo, \\ M. Gómez-Díez and F.M. Castejón \\ Additional information is available at the end of the chapter \\ http://dx.doi.org/10.5772/54311
}

\section{Introduction}

Multiple myeloma (MM) or plasma cell myeloma is a neoplastic proliferation of plasma cells that primarily involves the bone marrow but may originate from extramedullary sites [1-4]. Although it is uncommon in veterinary medicine, it has been reported in several species, including cats, dogs and, horses [1,3,5-10]. The frequency of MM in cats is slightly $<1 \%$ of all malignant neoplasms. Canine MMs account for only $0.3 \%$ of all malignancies in dogs. MMs account approximately $2 \%$ of all hematopoietic neoplasms in both dogs and cats [4]. Most of the reports in the literature are limited to 1 to 16 case studies [4,11-16]. However, in a recent report regarding the incidence of bone disorders diagnosed in dogs, MM was the second most frequently diagnosed neoplastic condition in canine bone marrow [17].

Similarly, MM is an extremely rare disorder in horses. Ten cases, nine from the literature and a new case, were described by Edwards et al. [1] and only six additional cases have been described lastly $[3,6-8,18]$. Because of the uncommonly diagnosis of equine MM, the prevalence of this neoplasm is unknown in the horse.

\section{Data of the patients with multiple myeloma}

MM is generally a disease of older animals, although some reports exist in young animals. In dogs, the average age of diagnosis is between 8 and 12 year-old [9-10,15,19-25].There is a report of MM in a younger dog, 4-year-old [26]. There is no apparent gender predisposition 
in dogs. Further, the largest retrospective study to date (60 dogs) included 30 males and 30 females [27].

The mean age of diagnosis in cats ranges between 12.5 and 14 years, and most of the cats with MM are older than 7 year-old [28,29,4,30,31,32,33,9]. According to the literature, the youngest cat with MM was 1.5 year-old [31]. A myeloma-related disorder has been described for a 19-month-old cat [34]. Males accounted for about 55-56\%. The age and gender in dogs and cats with MM are similar to those described in human patients. In a large retrospective study of 1027 people, the average age of diagnosis was 66 years and $59 \%$ were men [35].

$\mathrm{MM}$ is also a neoplasm of elderly horses, with mean age of 11 years at the moment of the diagnosis [1]. Horses with this condition have ranged in age from three months to 25 years. The youngest animals were a 1.6-year-old Quarter Horse mare [36] and a 3 month-old Quarter Horse colt [37]. Although it was suggested initially that it could be more common in Quarter Horses [1], there are too few reports in equids for statistical interpretation of this data. Both male (geldings and stallions) and female horses are represented equally.

\section{Current knowledge of the etiology and predisposing factors of MM in companion animals}

Factors associated with the development of $\mathrm{MM}$ in companion animals have not been identified. In human patients, exposure to high doses of ionizing radiation has been linked to MM development according to some studies [38-40]. In relation to x-rays, the results of many cohort studies in human beings have been inconsistent, in some cases suggesting that frequent exposure has a negligible effect and in other that it is a significant risk [41-43]. In one report of equine MM, one horse was used regularly for teaching radiology and Pusterla et al. [3] suggested that it might exists an association between exposure to $\mathrm{x}$-rays and neoplastic transformation.

Genetic and hereditary factors may also play a role in MM development [44-45]. Recurrent infections or antigen stimulation have been proposed as predisposing factors, although epidemiological studies have not been confirmed this association [46]. Infections with several virus diseases in human patients appear related to an elevated MM risk, although some data do not support a potentially causal relationship between these infections and MM [46-50]. In cats, a link between MM and virus such as feline leukemia virus (FeLV) and feline immunodeficiency virus (FIV) has not been identified, but a diagnosis of the disease among sibling suggests a familiar association [29]. The role of oncogenes, tumor-suppresor genes, cytokines, and their interaction with the bone marrow environment in the etiopathogenesis of the MM are currently being investigated in animal models. Overexpression of cell cycle regulators, such as cyslin D1 and disregulation of receptor tyrosine kinase have been implicated in the pathogenesis of plasma cell tumors and MM [51]. Progression of B cell lymphoma to $\mathrm{MM}$ and of solitary plasma cell tumors to MM in dogs and cats have been reported [52-53]. 


\section{Clinical signs}

The infiltration of various organ systems by neoplastic cells, the production of cytokines by the tumor or the bone marrow microenvironment, and the high circulating level of a single type of immunoglobulin lead to a wide array of clinical manifestations. Therefore, the clinical signs of MM vary with the level of plasma cell proliferation, the location and spread of the neoplastic plasma cells, and the nature and extent of the proteinuria $[3,4,9-10,15,33,54]$. The clinical signs are generally non-specific and include lethargy, renal failure, hemostatic abnormalities, anorexia, diarrhea and vomiting in small animals and weight loss, anorexia, fever, increased susceptibility to infections and limb edema in horses $[1,3,8,11,36]$.

\subsection{Increased susceptibility to infections}

MM patients are usually immunocompromised and thus highly susceptible to infections [55]. MM associated immunodeficiency is likely a multifaceted phenomenon secondary to decreased concentration of polyclonal immunoglobulin [56], suppression of macrophage-related factors influencing the normal B cell differentiation to plasma cells [57] in response to antigenic stimulation [58], decreased T helper cell function, increased rate of $\gamma$-globulin catabolism, neoplastic infiltration of bone marrow resulting in leukopenia [59], dysfunctional and/or decreased numbers of neutrophils, and defective complement activation [3-4].

In cats with MM, the most common infectious processes include periodontitis, chronic recurrent upper respiratory infections and terminal bacteriemia [4]. In horses with MM, the most common system affected by infectious disease is the lung, with several cases of severe pneumonia $[1,3,37,60]$.

\subsection{Bone pain and skeletal lesions}

Bone pain is considered one of the most common presenting complaints in human patients [61-62]. Skeletal abnormalities are commonly recognized in small animals, but uncommon in horses with MM $[1,3,63]$. Horses frequently had bone lesions, therefore, bone pain might manifest more as a gait abnormality and therefore, it could be misdiagnosed.

The percentage of cats with $\mathrm{MM}$ and radiographically-evident skeletal lesions was $58.3 \%$ $[2,4,13,63-66]$, similar to the $50-60 \%$ occurrence reported for dogs $[27,64]$. Skeletal lesions can be either solitary (well-circumscribed with areas of osteolysis or punched-out lytic areas) or multiple (generalized osteopenias) [4,27]. Rarely, pathologic fractures are seen. Skeletal lesions are typically identified in bones involved in active hematopoiesis (e.g. ribs, vertebrae, pelvis, and proximal and distal aspects of long bones). Other causes of focal osteolysis are rare in companion animals, but include carcinomas [67], giant cell tumors of bone [68], benign aneurismal bone cysts [69-71] and bone lesions secondary to tumor invasion [70,72-73]. Generalized osteopenias have also been diagnosed radiographically [4]. Demineralization of bone in humans is detected through measurement of bone mineral density, a technique not used routinely in veterinary medicine. Generalized osteopenias is not specific for MM, and may also be seen with nutritional, renal and metabolic disorders [74-77]. 


\subsection{Bleeding disorders}

Bleeding is a prominent feature of MM in human beings [78-82]. Clinically, hemorrhages occur in approximately one-third of dogs and one fourth of cats with MM $[4,27,29]$. In horses, the most common clinical manifestation is epistaxis $[1,3,6]$.

The pathogenesis of bleeding diathesis is likely multifactorial. The M-component may interfere with normal coagulation and lead to hemostatic defects by various mechanism that include inhibition of platelet aggregation and release of platelet factor, adsorption of minor clotting factors, induction of abnormal fibrin polymerization and functional decrease in calcium. In instances where myelophthisis is present due to profound bone marrow infiltration, thrombocytopenia may develop and contribute to hemorrhagic events [24].

\subsection{Hyperviscosity syndrome}

The hyperviscosity syndrome (HVS) in characterized by clinico-pathologic abnormalities that occur secondarily to increased serum viscosity, which is associated with the M-component. HVS is most commonly associated with immunoglobulin-M macroglobulinemia due to the high molecular weight of IgM [85]. However, it also can occur in presence of IgA, and rarely with IgG [27]. HVS leads to bleeding diathesis, neurological signs (such as seizures, depression, coma), congestive heart failure, renal failure and ophthalmic abnormalities, including tortuous and dilated retinal vessels, retinal hemorrhages and retinal detachment, sludging of blood within small vessels and impaired delivery of nutrients and oxygen to tissues [84].

Approximately $20 \%$ of dogs with MM develop this syndrome and it has been reported in cats $[4,13,19,23,54,85]$. There is a report that measured serum viscosity in a horse with MM [86]. The horse had a serum concentration of globulin of $9.6 \mathrm{~g} / \mathrm{dl}$ (reference range 3.5-4.5 $\mathrm{g} / \mathrm{dl}$ ) and a relative serum viscosity of 7 (reference range 1.4-1.7). In horses, edema is a common clinical signs in MM [1,3]. The genesis of limb edema is unknown, although blood hyperviscosity may be contributory. Increased vascular permeability has been proposed as a cause of edema accompanying osteosclerosis myeloma in human beings [87].

\subsection{Renal disease}

Renal disease occurs in approximately $22-50 \%$ of dogs and about $30 \%$ of cats with MM $[4,27]$. The pathogenesis of renal disease is commonly multifactorial and several mechanisms have been implicated in human patients [88-89]. In the majority of the cases, renal impairment is caused by the accumulation and precipitation of light chains, which forms casts in the distal tubules, resulting in renal obstructions. In addition, myeloma light chains are also directly toxic on proximal renal tubules, further adding to renal dysfunction [89-90]. Circulating monoclonal light chains are relatively freely filtered through the glomerulus, reaching the proximal tubule, where they are catabolized. Free light chains are endocytosed by proximal tubule cells, through a receptor-mediated process, by binding to the tandem scavenger receptor system cubilin/megalin. Then, they are endocytosed through the clathrin-dependent endosomal/lysosomal pathways and degraded within lysosomes [91-94]. In 
MM, excess light chain production overcomes the capacity of the tubular cells to catabolize the free light chains that appear in the tubular fluid of distal nephron segments. Therefore, they form tubular casts with Tamm-Horsfall protein (uromodulin), a glycoprotein-synthesized by the cells in the medullary thick ascending limb of the loop of Henle with affinity for monoclonal light chains. Light chains interact through their complementary determining region with a specific binding site on the Tamm-Horsfall protein and form aggregates and casts that subsequently lead to the tubular obstruction of the distal tubule and the thick ascending loop of Henle [95-97]. Tubular obstruction increases intraluminal pressure, reduces glomerular filtration rate and reduces interstitial blood flow, thus further compromising the renal function [90]). The rates of cast formation increase when light chains increase, although there is considerable diversity among the nephrotoxicity of light chains. The variable region of the light chain determines nephrotoxicity of the specific light chain by determining the affinity with Tomm-Horsfall protein [98-99]. It has been indicated that Tamm-Horsfall protein interacts with the hypervariable regions of the light chains. This region contains the amino acids that give diversity, and allow for interactions with several proteins to promote antigen binding by immunoglobulins [100-101]. In addition, the variable region of the light chain determines the specific type of renal damage. Both lambda and kappa light chains are nephrotoxic, but lambda light chains are more frequently involved in the formation of amyloid than kappa [102]. The relationship between the type of light chain and the severity and type of renal damage has not been investigated in animals yet.

In addition of casts formation, endocytosis of light chains by renal tubular cells induces proinflammatory cytokine production (interleukin- 6 and 8 , tumor necrosis factor- $\alpha$ ). These proinflammatory cytokines promote infiltration by inflammatory cells that produce metalloproteinases and increase transforming growth factor-b production, resulting in matrix protein deposition and fibrosis and further compromising the ability of the nephron to restore function [103]. Light chains endocytosis might also cause tubular cell necrosis, leading to more severe renal dysfunction [104], but the exact mechanism has not been described. It has been hypothesized that the aggregation of light chains after endocytosis initiates a cascade leading to tubular cell death [105].

Other mechanisms that lead to renal insufficiency are tumor infiltration within the renal parenchyma, hypercalcemia, amyloidosis, decreased renal perfusion due to the HVS, dehydration, ascending urinary tract infections and Bence-Jones proteinuria [4, 27]. In human patients with MM, hypercalcemia is the second most common cause of renal failure. Hypercalcemia is also probably an important predisposing factor to renal dysfunction in animals with MM, since a tight relationship between renal failure and hypercalcemia has been described in many reports in veterinary medicine [106-108] Hypercalcemia interferes with renal function and impairs renal concentrating ability, causes vasoconstriction of renal vasculature and enhances diuresis.

\subsection{Heart disease}

Heart disease may occur in patients with MM as a consequence of HVS related to myocardial hypoxia and increased cardiac workload. In addition, amyloid deposition in the myo- 
cardium and anemia may exacerbate the severity of this condition [109]. Approximately $50 \%$ of the cats with MM in one study had idiopathic heart murmur [4]. Recently, three cases of cats evaluated for congestive heart failure with acute collapse, tachypnea, increased respiratory effort, and pulmonary crackles, have been reported secondarily to HVS [54].

\subsection{Other clinical signs}

Neurological manifestations often complicate the course of $\mathrm{MM}$, but direct involvement of the central nervous system in rare in human patients, although there are some cases reported [110-113]. Similarly, neurological signs are uncommon manifestations of MM in animals. However, it is well recognized that MM may lead to abnormalities of the central nervous system either as a result of spinal cord compression by the neoplasm arising within a vertebra or due to pathological fracture of a vertebra weakened by tumor infiltration [114-115]. It could also be due to the HVS where sludging of blood within the vasculature results in central nervous system hypoxia [116]. Neurological signs associated with MM have been reported in horses [1,7], cats [31] and dogs [22,114]. Edwards et al. [1] described the cases of three horses with rear leg paresis and/or ataxia. Spinal cord compression by an extradural tumor mass was observed in one of the two horses in which the spinal canal was examined. McConkey et al. [7] observed a horse with hind ataxia progressing to paralysis, with dysphagia and ptyalism. These clinical signs were attributed to neoplastic involvement of the trigeminal nerve. Similarly, Appel et al. [31] presented the case of a cat with hind limb locomotor difficulties, signs of pain along the lumbar portion of the vertebral column, with altered motor function and moderate muscle atrophy. In this case, survey radiographs revealed osteolytic lesions in lumbar vertebras [31].

In MM patients, peripheral neuropathy has for a long time been considered as mainly secondary to the tumor, following a direct compression (radicular or medullar), light chain deposits (amyloidosis), cryoglobulinemia or an autoimmune mechanism [117-121]. A paraneoplastic polyneuropathy is seen in association with IgM monoclonal gammopathy associated with MM, Waldenstrom's macroglobulinemia, primary amyloidosis and lymphoma, as well as monoclonal gammopathy of undetermined significance. IgM-M proteins have autoantibody activity and have been shown to bind to myelin associated glycoprotein resulting in a demyelinating peripheral neuropathy [121]. However, increased levels of cytokines are thought to cause the paraneoplastic neuropathy rather than an immune-mediated mechanism [122-123]. Furthermore, with the use of new drugs, the iatrogenic neurotoxicity has become the leading cause of peripheral neuropathy in people [124-126]. The commonest nerve involvement appears to be in the form of sensory-motor axonal neuropathy followed by sensory-motor demyelinating neuropathy [117].

In companion animals, paraneoplastic neuropathies have been reported sporadically in malignant tumors, and include bronchogenic carcinoma, insulinoma, leiomyosarcoma, hemangiosarcoma, undifferentiated sarcoma, synovial sarcoma and adrenal adenocarcinoma [114,127-129]. Viviers and Dobson [22] described the case of a 12-year-old female German Shepherd dog that developed progressive hindlimb followed by forelimb ataxia with tetraplejia. Neurological examination suggested lower motor dysfunction. MM was diagnosed 
by biochemical evaluation, radiography and bone marrow aspirate. An electromyogram revealed positive sharp waves and fibrillation potentials in the skeletal muscles of the limbs, suggesting a polyneuropathy. Motor function started to improve four weeks after commencing treatment. According to the authors, polyneuropathy in this dog appeared as a paraneoplastic syndrome secondary to MM [22].

Cutaneous involvement in MM has also been described in animals, although it seems to be unusual. Mayer et al. [24] described the case of an 8-year-old Rottweiler dog with more than 50 soft cutaneous and subcutaneous nodules, ranging from 0.5 to $2.5 \mathrm{~cm}$ in diameter, located primarily on the ventral aspects of the thorax and abdomen and the medial aspect of the thighs. Histopathological examination of excised subcutaneous modules revealed MM. More recently, Fukumoto et al. [16] presented the case of a 7-year-old male, mixed breed dog with more than 40 cutaneous nodules ranging from 0.5 to $1.0 \mathrm{~cm}$ in diameter, mainly on the abdomen and inguinal region. Cutaneous involvement has not been described in horses with MM.

\section{Diagnosis aids of multiple myeloma in veterinary medicine}

\subsection{Hematology}

Anemia is a prominent feature of MM, it is commonly associated with clinical progression in human patients and occurs in more than two thirds of all patients [130-132]. Similarly, approximately $30 \%$ of dogs and $75 \%$ of cats with MM have a normocytic normochromic non-regenerative anemia $[4,10,26-27,32-33]$ and anemia is also invariably present in horses with MM.

The pathogenic mechanisms involved in the anemia are chronic inflammation, tumor hemorrhage and/or hemostatic abnormalities, myelophthisis, increased red blood cell destruction induced by the HVS, plasma expansion secondary to the osmotic effect of the paraproteins and red cell destruction by neoplastic cells $[4,27,29]$. In cats, erythrophagocytosis by neoplastic plasma cells [32], mast cells [133]), lymphocytes [134-135] and histocytes [136] has been observed. In the same way, there are several reports of phagocytic plasma cells in people with MM [137]. Although erythrophagocytic plasma cells in humans with $\mathrm{MM}$ are rare, neoplastic plasma cells have been observed with phagocytosed platelets and granulocytes [138]. The mechanism of hemophagocytosis in MM is unclear, as plasma cells have not phagocytic function under normal circumstances. Results of the direct antiglobulin test in humans are almost always negative, suggesting hemophagocytosis by neoplastic cells is not an autoimmune function [137]. It has been speculated that phagocytic plasma cells may arise as an expansion of a rare B-cell clone with innate phagocytic potential [137]. A single case of phagocytic plasma cells aberrantly expression CD15 (normally found on neutrophils and monocytes and involved in phagocytosis) has been reported in human beings [139].

Nevertheless, anemia of chronic disease appears to be of utmost importance in MM. Interleukin-1 and tumor necrosis factors are capable of suppressing erythropoiesis [130]. Anemia 
has broad implications in these patients. First, the low hemoglobin concentration and packed cell volume have been associated with poor quality of life in people, and affect daily activity. Second, anemia has an impact on the cardiovascular system. In fact, anemia has been shown to induce or aggravate hypoxia and ischemic complications. Third, anemia has been shown to be a poor prognostic factor in MM [140-142].

Data concerning white blood cell count (total and different subpopulations) are not consistent in animals with MM. It has been found lymphopenia [24,30,32], leukocytosis due to neutrophilia $[4,8]$, neutropenia with lymphocytosis [31], leukopenia [1,25,37], leukocytosis with neutrophilia and lymphocytosis [31], neutropenia [16], neutrophenia with lymphopenia [18], pancytopenia [10] and absence of white blood cell abnormalities [3,6,22].

Thrombocytopenia is reported in approximately one third of all canine patients of MM $[10,25,27]$. It has also been described in cats $[4,29]$ and horses $[18,37]$. However, there are many other reports of MM in veterinary medicine with patients that show normal number of platelets [3,6-8,16,22,24,31-32]. Thrombocytopenia that could promote bleeding disorders, is proposed to result from infiltration of bone marrow by malignant plasma cells, consumption of platelets as part of thrombohemorrhagic syndrome, such as disseminated intravascular coagulation, shortened platelet half-life or immune-mediated destruction, even though the latter 2 mechanisms have yet to be verified in veterinary medicine [10,27,30,64,142-143].

\subsection{Blood clinical biochemistry}

\subsubsection{Serum protein concentrations and serum protein electrophoresis}

Hyperproteinemia, specifically hypoalbuminemia and hyperglobulinemia is very common in $\mathrm{MM}$, but not an invariable feature. Hypoalbuminemia has been described consistently in $\mathrm{MM}$ in dogs [9,15-16,22-24], cats [3,9,29,32] and horses [1,3,18]. However, in the three animal species, there are some reports that reported serum albumin concentrations within the reference range in animals $[6-8,31]$.

The mechanisms of the hypoalbuminemia are unknown, but in human beings is primarily related to the extent of the proliferation of the MM and it is therefore of diagnostic and prognostic importance [144]. Several studies have suggested that low serum albumin concentrations correlate with increased serum concentrations of interleukin- 6 , a potent myeloma cell growth factor, reflecting disease severity and cell proliferation [145-146]. Interleukin-6 is a multifunctional, pro-inflammatory cytokine that stimulates B cell maturation and proliferation and overproduction has been demonstrated in a variety of B-cell malignancies [147].

The neoplastic plasma cells are responsible for an overproduction of a homogeneous or monoclonal immunoglobulin product, known as paraproteins o M-component. The paraproteins may be complete immunoglobulin, free light chains, light chains fragments or polymers, or partial immunoglobulins missing one or both chains [148]. The term monoclonal gammopathy is commonly used to define hyperglobulinemia characterized by an electrophoretic pattern with a sharply defined peak that is usually in the $\beta$ - or $\gamma$ - region and is narrower than the albumin peak $[9,149]$. When 2 narrow peaks with these features are 
recognized, the term biclonal gammopathy is often used. Monoclonal gammopathies are associated with production of a single clone of immunoglobulin owing to clonal expansion of neoplastic lymphoid cells, such as plasma cells in MM and B cells in lymphoma [9]. In contrast, a polyclonal gammopathy is characterized by a broader peak or multiple peaks in the $\gamma$ - or $\beta-\gamma$ regions. Polyclonal gammopathies are associated with chronic antigenic stimulation that occurs in chronic infections and other inflammatory conditions [148,150-152]. The term oligoclonal gammopathy refers to an electrophoretic pattern that is similar to a monoclonal one, but in which the globulin peak is slightly wider than the albumin peak $[9,149]$. Oligoclonal gammopathy may occasionally occur in animals with chronic inflammation or infectious disease [9].

Although monoclonal gammopathy is the laboratory landmark of MM, other conditions occasionally can induce a monoclonal gammopathy in animals, such as chronic inflammation (leishmaniosis, ehrlichiosis, chronic pioderma, feline infectious peritonitis) [149-150,153-155], amyloidosis [156-157], B-cell lymphoma [149], Waldenströms macroglobulinemia [158-159] and monoclonal gammopathy of undefined significance (MGUS) [160]. The inclusion criterion for MGUS are M-protein and $<10 \%$ bone marrow plasmacytosis, with no evidence of lytic lesions, light chain proteinuria or other clinical, hematologic, and biochemical abnormalities [161-162]. MGUS occurs in 1-2\% of people over the age of 50 and 3\% of people over the age of 70 [162]. A significant proportion (25\%) of these will evolve within 20 years into MM, primary amyloidosis, macroglobulinemia or another lymphoproliferative disease [162].

In dogs affected by MM, the incidence of $\operatorname{IgA}$ and $\operatorname{IgG}$ is comparable, whereas in cats and horses IgG is most commonly involved [1,3-4,27]. In fact, of the 25 published feline MM with immunoelectrophoresis results, 20 had IgG gammopathies, and 5 had IgA gammopathies $[2,13-14,85]$. Similarly, there are some reports of IgA gammopathies in horses with MM $[3,8]$.

Biclonal gammopathy, with two M-components has been reported in humans [163-165], even though it was found to be very rare, occurring in about $1 \%$ of human beings with MM [166]. Biclonal gammopathies have been described in lymphoproliferative disorders in dogs and cats $[2,9,19,23,167-168]$ including MM. The term biclonal is applied to the electrophoretic pattern and does not always correlate with true biclonal expansion because the biclonal electrophoretic may arise from a single clone of B-cells, usually mature plasma cells that produce one type of immunoglobulin with different dimerization patterns [9]. The biclonal pattern may also occur from production of two different classes of immunoglobulins, usually IgG and IgA, by two separate cell clones [23]. However, production of separate heavy chain isotypes by a single clone of neoplastic cells, may result from isotype switching, which occurs normally during B-cell maturation [9].

The prevalence of biclonal gammopathy in companion animals is unknown, but it could be higher than reported. In many clinical veterinary laboratories, serum protein electrophoresis is performed using cellulose acetate as the support medium. However, better separation of protein fractions may be obtained using agar cell electrophoresis or capillary zone electrophoresis. Facchini et al. [9] reported two cases (dog and cat) with gammopathies associated 
with MM that were interpreted as oligoclonal by standard cellulose acetate electrophoresis but were determined to be biclonal con capillary zone electrophoresis.

MMs in veterinary patients lacking hyperglobulinemia have also been described [10]. The authors propose that the lack of hyperglobulinemia resulted from either M-protein associated secondary hypogammaglobulinemia or the IgA nature of the M protein. Secondary hypogammaglobulinemia with an immunosuppressive phenomenon associated with $\mathrm{MM}$ is reported to occur in about $10 \%$ of human MM patients, and in a report, is most commonly seen in secretory immunoglobulin A- MM [169-172]. The mechanism underlying MM-associated hypogammaglobulinemia is unclear, but recent work suggest that appropriate B-cell maturation and immunoglobulin production are impaired by defects in CD4+, CD45R+, naïve T cells and increases in CD8+, CD11b1+ memory T cells [173-174]. The depression of normal immunoglobulin production associated with exuberant $\mathrm{M}$ protein production has been described anecdotally, but not specifically described in dogs with MM [64]. Seelig et al. [10] supported their hypothesis in the immunoglobulin quantification data, which indicate massive production of the immunoglobulin A M-protein and mild to moderate decreases in immunoglobulins $\mathrm{G}$ and $\mathrm{M}$ in a dog.

Cryoglobulinemia has also been described in human patients with MM [175-176]. Cryoglobulins are proteins, usually immunoglobulins that precipitate as serum is cooled to temperature less than body temperature and dissolve upon rewarming. They are most commonly evident as a white gelatinous material but may sometimes appear crystalline or flocculent [177] Cryoglobulinemia is rare in animals and are limited descriptions in dogs with MM $[114,178]$, in a dog with Waldenström's macroglobulenia [179], in a cat [28], in a horse with lymphoma [180], and in several horses with glomerulonephritis [181-182]. In human patients, cryoglobulins are classified into 3 groups on the basis of their immunoglobulin composition. In type- 1 cryoglobulinemia a single monoclonal immunoglobulin, usually IgM is present. This is most commonly associated with lymphoproliferative disorders such as MM, Waldenström's macroglobulinemia, lymphoma, and lymphocytic leukemia, but occasionally can develop in conjunction with immune-mediated diseases [177]. In type II cryoglobulinemia, a monoclonal immunoglobulin, usually IgM complexes with polyclonal IgG, whereas in type III cryoglobulinemia, polyclonal immunoglobulins, usually immunoglobulin $\mathrm{M}$ complex with polyclonal immunoglobulin G. Type II and III cryoglobulinemia and may develop secondary to infection, immune-mediated diseases or very rarely, lymphoproliferative disease. In some instances, an underlying disease is not found and the cryoglobulinemia is described as essential. Using this classification system, type-I and mixed cryoglobulinemia in dogs, horses and cats have been described. Two dogs with MM had type-I immunoglobulin A cryoglobulinemia [114,178] and the dog with Waldenström's macroglobulinemia had type-I immunoglobulin M cryoglobulinemia [179]. Another dog had an essential mixed immunoglobulin G-M cryoglobulinemia and cryofibrinogenemia [183], and although a thorough investigation for the underlying disease was not performed, the diagnosis was supported by resolution and lack of recurrence of clinical signs when the dog was maintained in a warm environment [183]. A cat had type I immunoglobulin G cryoglobulinemia in association with MM [28]. 
The typical clinical signs of cryoglobulinemia are purpura, cold intolerance, acrocyanosis and ulceration, necrosis and gangrene of the skin of the distal extremities [184]. However of the cases of cryoglobulinemia reported in the veterinary literature, only $1 \mathrm{dog}$ [183] and 2 horses [180,182] had typical lesions. Necrosis of the pinnae occurred in the dog [183] and in 1 of the horses [180] and distal limb swelling and ulceration in other horse [182]. Similarly, $<50 \%$ of human patients with cryoglobulinemia have typical clinical signs even in cold conditions [184]. The lesions develop as a result of precipitation of cryoglobulin in small-diameter blood vessels, which causes vascular occlusion and tissue ischemia. Subsequently, inflammation may develop at the site of precipitation secondary to complement fixation by immunoglobulin G [185]. Despite extensive investigation, the physical and chemical characteristics accounting for the temperature-dependent solubility of cryoglobulins have not been determined. Proposed mechanisms include altered amino acid or carbohydrate content of the cryoglobin, leading to abnormal interactions between water and the protein [185].

\subsubsection{Serum urea and creatinine concentrations}

Azotemia is present in half of MM human patients when first evaluated [78-79]. Similarly, many animals with MM show azotemia when presented [1,4,10,24,27,29], whereas there are other cases with serum urea and creatinine concentrations within the reference limits $[3,6,22]$. Probably these differences depend on the existence of renal kidney and on the degree of hydration.

\subsubsection{Serum total and ionized calcium concentrations}

Hypercalcemia has been reported in approximately $15-20 \%$ of dogs and $20-25 \%$ of cats affected by MM $[4,29,65]$. Similarly, hypercalcemia seems to be common in horses with MM $[1,3,8]$, although there is a report of hypocalcemia in one horse with MM [18].

Hypercalcemia is a complication of uncontrolled osteolysis, influenced in part by osteoclast activation factor and in human patients has been associated with extensive osteolytic disease [86]. However, MM-associated hypercalcemia is not reported as frequently as bone lysis $[4,27,35,64]$, perhaps because disease progression is usually slow, allowing for appropriate metabolic controls. Other mechanisms of hypercalcemia are the release of an osteoclast activating factor by either the bone marrow microenvironment or by neoplastic cells located in bone [186-190]. In humans, interleukin-1, interleukin-6, tumor necrosis factor and the receptor activator of the nuclear factor kappa B ligand (RANKL) all modulated osteoclast activity and may contribute to hypercalcemia [191]. Paratyroid hormone related peptide (PTH-rP) also may contribute to the pathogenesis of MM-related hypercalcemia. It seems that essentially every cell of the body makes PTHrP under normal conditions [192-193]. It has a broad range of physiological functions, including stimulation of bone resorption, vasorelaxation, and cell proliferation, regulation of placental calcium transport, organogenesis, parturition, lactation, and vascular smooth muscle proliferation and development of the skeletal system [193]. Despite its wide distribution of the body, PTHrP is normally present in minute amounts in the circulation [193-194] and high serum PTHrP concentrations have been found in conjunction only with pathologic conditions, principally malignancy [194-195]. PTHrP 
may be synthesized by normal cells activated by the presence of a malignancy or by neoplastic cells. There is a report of a horse with MM and high concentrations of PTHrP [8]). High levels of PTHrP have been also described in other neoplasms, such as thymoma [196], nasal carcinoma [197], squamous cell carcinomas [198], angiomyxoma [199], mammary carcinoma [200], lymphoma [201-203] adenocarcinoma of the apocrine gland of the anal sac [203] and malignant melanoma [204].

The measurement of ionized calcium is recommended to confirm hypercalcemia in these patients, because binding of calcium by the $\mathrm{M}$ protein will increase total calcium concentration, while ionized calcium will remain within normal limits [205]. Therefore, increased ionized calcium concentrations supports true hypercalcemia. There is a recent report that present a case of MM in a dog with increased total serum calcium concentration, but with serum ionized calcium concentrations within normal limits [25]. The authors suggested that the majority of the calcium was protein-bound to serum $\mathrm{M}$ proteins. In fact, serum calcium exists in two major fractions, free and protein bound. A small portion of calcium is bound to other small anions such as citrate, lactate, and phosphate. Because ionized calcium is the physiologically active species of blood calcium, it is ordinarily maintained within very narrow limits by rigidly controlled mechanisms [205-206]. Approximately half of normal total serum calcium is bound to negatively charged sites on albumin. Human MM has been reported to bind calcium on the Fab portion of the globulin molecules [148].

$\mathrm{MM}$ is frequently complicated by an increase in the concentration of ionized calcium, which if persistent leads to secondary nephrogenic diabetes insipidus and loss of the renal medullary concentration gradient causing polyuria and polydipsia [25].

\subsubsection{Alterations in the coagulation profile}

Approximately $50 \%$ of dogs affected by MM have abnormal prothrombin and partial thromboplastin times $[149,207]$ and these abnormalities have also been found in horses $[6,18,37,86]$ and cats $[4,29]$. However, other animals with MM had normal bleeding times [3,22].

Coagulation defects can result from paraproteins interference with clotting factors, protein coating of platelets leading to thrombocytopenia and binding of the Fab fragment of the Mprotein to fibrin, preventing aggregation [116,208].

\subsubsection{Alterations in serum sodium concentrations}

Three horses with MM were hyponatremia [1]. The decreased concentrations could have resulted from displacement of the aqueous phase of plasma by the hyperglobulinemia. However, true hyponatremia in human beings with MM has been described. Suggested mechanism include displacement of sodium by cationic paraproteins, decreased plasma water secondary to unusual hydration characteristics of paraproteins, and syndrome of inappropriate antidiuretic hormone release [209-210]. Alterations in serum sodium concentrations do not appear to be common in small animals. 


\subsubsection{Alterations in serum cholesterol concentrations}

Hypocholesterolemia has been noted in approximately $69 \%$ of affected cats in one study [4]. Similarly, hypocholesterolemia was found in a horse with MM [1]. The incidence in cats is higher than in human patients [211-212]. Serum cholesterol concentrations are thought to be correlated inversely with globulin concentrations [35,211]. It has been postulated that the hypocholesterolemia is the result of a down-regulation of cholesterol production by the liver to maintain oncotic pressure in the face of hyperglobulinemia [78]). The main causes of hypocholesterolemia in veterinary medicine include protein-losing enteropathies, severe malnutrition, hepatic insufficiency or hyperthyroidism [213-215].

\subsection{Urinalysis}

Proteinuria, detected by routine urinalysis is present in $90 \%$ of human patients with MM [216-221]. In the same way, proteinuria using dipsticks has been found in horses $[1,3,6]$, dogs $[10,22]$ and cats $[4,28,30,32]$ with MM. However, dipsticks detect primarily albuminuria and therefore, the sulfosalicylic acid test (SSA) provides greater sensitivity for globulin detection but specificity is low due to the concomitant detection of albumin, globulin, Bence Jones proteins, proteases and polypeptides. False positive SSA results may occur with penicillin and its derivatives, tolbutamide or sulfisoxazole metabolites, or certain contrast media in the urine [222]. In people, false positive results for Bence Jones proteins detected by means of heat precipitation can occur due to excessive amount of polyclonal light chain proteins in patients affected by a variety of conditions, including connective tissue diseases, non-plasmacytic tumors and chronic renal failure $[4,216,222]$. Therefore, urine protein electrophoresis remains the preferred diagnostic modality to detect monoclonal proteinuria, even is not always used in veterinary medicine.

Bence Jones proteinuria has been estimated to occur in approximately $25-40 \%$ of dogs an approximately $65 \%$ of cats with MM $[4,27,29]$. Similarly, it has been determined in horses with MM [1,3].

\subsection{Diagnostic ancillary aids}

Survey radiographies and echographies are required for screening of skeletal lesions and identification of abdominal organ neoplasia respectively. Furthermore, a funduscopic examination should be carried out in patients suspicious of MM, mainly in small animals, in order to rule out ocular lesions associated with the HVS, such as retinal hemorrhages, retinal detachment, venous tortuosity, dilation, sacculation, and blindness.

As explained before, skeletal lesions vary from areas of osteopenias observed in early stages of the disease to lytic lesions typical of later stages. Biopsy and histopathology of a lytic lesion may sometimes be necessary for a definitive diagnosis. Survey radiographies are commonly performed now in small animals with MM, because increased clinician awareness of the lesions, better quality radiographs and increased knowledge about the disease. In horses with MM, survey radiographies are less used, probably because of the higher incidence of skeletal lesions of other origin (sport horses). Lung radiography is recommended in equine 
patients with $\mathrm{MM}$ in order to rule out pneumonia, one common finding in these cases $[3,18]$. In addition, hepatomegaly (58\%), splenomegaly (25\%), cardiomegaly $(67 \%)$ and renomegaly (9\%) have been detected in cats with MM $[4,29]$.

The most common ultrasonographic abnormalities involved the spleen and the liver and to a lesser extent the kidneys [4]. In cats, the most consistent finding in MM is splenic enlargement and diffuse or nodular hypoechogenicity. The most consistent hepatic abnormality is diffuse hyperechogenicity and enlargement [4]. Bone marrow cytology should be done to confirm the diagnosis. A detailed description of the histopathological characteristics in bone marrow and in other organs after necropsy, consistent with MM is out of the scope of the present review.

\subsection{Diagnostic criteria}

Current published recommendations for determining a diagnosis in veterinary medicine indicate that the animal should have at least 2 of the following 4 criteria: 1) Bone marrow plasmacytosis with $>20 \%$ plasma cells; 2) Monoclonal gammopathy based on serum protein electrophoresis; 3) Osteolysis and 4) Light chain (Bence-Jones) proteinuria (2). These criteria are unweighted for animal patients. In human patients, criteria are weighted as 'major' and 'minor' and accommodate lower plasma cell percentages (17). In people, confirmation of $\mathrm{MM}$ requires first that the patient be symptomatic (i.e. have bone pain) or have anemia, hypercalcemia, azotemia, hypoalbuminemia, or bone demineralization. The diagnostic criteria of MM are then applied. Major criteria include: 1) plasmacytoma(s) with biopsy; 2) marrow plasmatocytosis $>30 \%$; 3) M-protein with $>3.5 \mathrm{~g} / \mathrm{dl}$ immunoglobulin $\mathrm{G}$ or $2.0 \mathrm{~g} / \mathrm{dl}$ immunoglobulin A and 4) $\kappa$ or $\lambda$ chain excretion on 24-h urine protein electrophoresis. The 4 minor criteria include: a) marrow plasmacytosis with $10-30 \%$ plasma cells; b) M-protein at values less than indicated above; c) lytic bone lesions and d) $>50 \%$ normal serum immunoglobulin concentration. If the diagnosis includes major criteria, then any 2 of the 4 will suffice, or major criterion 1 plus minor criterion $b$, c, or $d$; or major criterion 3 plus minor criterion a or $c$. If the diagnosis is based on only minor criteria, then it must include the first and second criteria ( $a$ and $b$ ), plus 1 of the remaining 2 criteria ( $c$ or $d$ ). This system has been recently incorporated for the diagnosis in animals [4,10,24,31-32]. However, some modifications have been introduced. Plasma cell atypia has been included as a criterion when marrow plasmacytosis was between 10 and 20\%. In humans, nuclear-cytoplasmic maturation asynchrony, nuclear immaturity, and pleomorphism are considered reliable markers for distinguishing neoplastic cells from reactive plasma cells [223]. In addition, reactive plasma cells usually do not exceed 5\% of all nucleated cells in marrow and are well differentiated [223-224].

\section{Treatment options in veterinary patients with $\mathrm{mm}$}

Treatment of MM with oral melphalan and glucocorticoids (prednisone or prednisolone) is the standard of therapy due to its dual ability to reduce the bulk of the tumor and the symptoms of the decrease $[16,22-25,31-33,225]$. Although complete eradication is only rarely ach- 
ieved, chemotherapy is often effective in decreasing tumor burden, reducing serum immunoglobulin levels, promoting bone remodeling and providing symptomatic relief. Further, this treatment leads to improved quality and possible duration of life $[27,225]$ and is also used in human patients with MM [226-230].

Melphalan is an alkylating agent whose oral absorption is unpredictable, requiring administration to be made preferable on the empty stomach. In dogs, melphalan is initially administered at $0.1 \mathrm{mg} / \mathrm{kg}$ PO once a day for 10 days and then $0.05 \mathrm{mg} / \mathrm{kg}$ PO every other day. In cats, they are administered at $0.5-2.0 \mathrm{mg} / \mathrm{kg}$ PO once a day. Melphalan is combined with glucocorticoids, prednisone [22,24-25,42] or less common, prednisolone [25,30-31]. Glucocorticoids have been shown to induce apoptosis in vitro via inhibition of I $\kappa$ activation and decreased nuclear factor $\kappa B$ activity [231-232]. Prednisone in dogs with MM is generally administered at $1.0 \mathrm{mg} / \mathrm{kg}$ for the first 10 days of therapy and then, decreased to $0.5 \mathrm{mg} / \mathrm{kg}$ every other day $[22,24-25,32,225]$. This combination treatment is continued indefinitely, until relapse or myelosuppression.

Other alkylating drugs including cyclophosphamide, chlorambucil and 1(2-chloroethyl)-3cyclohexyl-1-nitrosourea (CCNU) have also been used to treat MM in small animals [10,233]. The addition of cyclophosphamide to a prednisone- melphalan regimen may be beneficial to patients with severe clinical signs and/or hypercalcemia. Due to its platelet-sparing effect, cyclophosphamide may be used in place of melphalan in thrombocytopenic patients, although this drug can have severe suppressive effects on other bone marrow lineages [234-237]. Chorambucil, administered at $0.2 \mathrm{mg} / \mathrm{kg}$ PO once daily has been used successful for the treatment of immunoglobulin M macroglobulinemia in dogs [159].

Combination chemotherapy protocols incorporating vincristine, carmustine, melphalan, cyclophosphamide and prednisone or vincristine, melphalan, cyclophosphamide and prednisone have been used in human beings, but outcomes are essentially comparable to those of patients with melphalan and prednisone alone [238-241]. The administration of high dose dexamethasone in conjunction with vincristine and doxorubicin was investigated in humans with refractory $\mathrm{MM}$ and resulted in a response greater than $50 \%$. Rapid tumor response, alleviation of bone pain, resolution of hypercalcemia and absence of damage to bone marrow stem cells were remarkable advantages to this treatment combination [239]. Anecdotally, in dogs, responses of a few months duration have been achieved with a combination of doxorubicin, vincristine and prednisone in lymphoma [242-243] and in MM [10].

The efficacy of inteferon for the treatment of MM is controversial [244-245]. While a response rate of approximately $20 \%$ was reported in humans with relapsed MM, the addition of interferon to standard chemotherapy approaches failed to provide a significant benefit to the overall survival time in a meta-analysis of 2286 patients [244]. However, there is other report that stated that even though most interferon benefits to MM patients are relatively small when viewed in the light of survival expectancies, they seem clinically relevant. Since median overall survival of conventionally treated MM patients ranges between 30 and 50 months, 3-7 months gains of life amount to a increase of 10-25\% [244]. 
High-dose chemotherapy in association with autologous transplantations using bone marrow or blood-derived stem cells is now widely accepted for the treatment of hematological malignancies including MM. This approach yielded to complete remissions in refractory human patients, but mortality rate due to bone marrow suppression was high. Contamination of most bone marrow and blood stem cell samples with neoplastic cells within the autograph resulted in recurrence of disease, emphasizing the need of optimize purging techniques [246-250]. Autologous bone marrow transplant has also been added to chemotherapy in the treatment of some malignancies in companion animals, such as lymphoma and acute myeloid leukemia [251-253].

In human patients with MM, biphosphonates such as pamidronate, have been used to prevent or to delay the onset of bone lesions and associated bone pain [254-257]. Bisphosphonates have been administered in dogs with appendicular osteosarcoma [258-259] and with malignant histiocytosis [260], but they have not been used in veterinary patients with MM.

Treatment of patients affected by indolent MM with the anti-angiogenic agent thalidomide resulted in a $66 \%$ response rate and the drug appeared to have potential to delay the onset of clinical signs associated with the disease [261-262]. The efficacy of thalidomide for the treatment of refractory relapsed MM has also been confirmed [263-265]. Studies evaluating the possible efficacy of thalidomide for the treatment of MM in companion animals are lacking. Bortezomib, a proteasome inhibitor, induces apoptosis of MM cells and inhibits their binding to bone marrow stromal cells, which otherwise would trigger the transcription of interleukin-6 via an NFkB-dependent pathway. In different studies a $25 \%$ response rate was achieved in human beings with $\mathrm{MM}$ and an overall survival time of 16 months. Furthermore, addition of dexamethasone to the treatment regimen improved responses in $19 \%$ of treated patients [227-228,264,266].

Additional, some patients experience severe clinical signs secondary to hypercalcemia, renal dysfunction, HVS or pathologic fractures will require palliative therapy specifically directed to the clinical complications of the disease.

\section{Prognosis of companion animals with multiple myeloma}

Unfortunately, the prognosis of companion animals with MM is poor. The mean survival time in dogs treated with MM and treated with melphalan, cyclophosphamide and prednisone is 540 days after diagnosis [27]. In dogs, negative prognostic factors include extensive bone lesions, hypercalcemia and light chain proteinuria. Renal insufficiency and poor initial response to therapy also may be associated with decreased survival times [27]. In a study of 9 cats with MM, it was found that hypercalcemia, pathologic fractures, anemia, Bence-Jones proteinuria, azotemia, persistent elevations in serum protein concentrations at 8 weeks after treatment and little or no clinical improvement were poor prognostic indicators and reflected a more aggressive form of the disease [29]. Survival time for such cats did not exceed 14 days, with a median of 5 days. In contrast, normocalcemia, lack of azotemia, absence of pathologic fractures, no anemia, absence of Bence-Jones proteinuria and a normal serum 
protein 8 weeks after commencement of treatment reflected a less aggressive form with a median survival of 387 days (range between 120 and 720 days) [29].

In a study, a possible relationship between prognosis and immunoglobulin isotype was suggested in cats with MM [2], even though there are few detailed cases. Although immunoglobulin A appears to be less commonly produced than immunoglobulin $\mathrm{G}$ in cats, as described before, the published cases with immunoglobulin A paraproteins had visceral involvement and decreased survival time (ranging from a few days to 6 months) [12,65,267-268]. Either immunoglobulin has been associated with clinical signs of HVS, including cardiac insufficiency, retinal hemorrhages and neurological signs $[85,268]$. This phenomenon relates to the size of the paraproteins and the degree of hyperglobulinemia. Since immunoglobulin A may assume a dimeric or multimeric form, it may be more commonly associated with hyperviscosity than immunoglobulin G. HVS can contribute to decreased survival time in animals with MM [13,23,54,85].

The lifespan of horses diagnosed of MM usually does not exceed two years [1,3,6,8]. There is not any published case of equine MM that attempted chemotherapy and most horses are euthanized owing to the advance stage of the disease.

\section{Author details}

A. Muñoz ${ }^{1}$, C. Riber ${ }^{1}$, K. Satué2 ${ }^{2}$ P. Trigo ${ }^{3}$, M. Gómez-Díez ${ }^{3}$ and F.M. Castejón ${ }^{3}$

*Address all correspondence to: pv1mujua@uco.es

1 Department of Animal Medicine and Surgery, School of Veterinary Medicine, University of Córdoba, Córdoba, Spain

2 Department of Animal Medicine and Surgery, School of Veterinary Medicine, Cardenal Herrera-CEU University, Valencia, Spain

3 Equine Sport Medicine Centre, School of Veterinary Medicine, University of Córdoba, Córdoba, Spain

\section{References}

[1] Edwards DE, Parker JW, Wilkinson JE, Helman RG. Plasma Cell Myeloma in the Horse. A Case Report and Literature Review. Journal of Veterinary Internal Medicine 1993; 7(3) 169-176.

[2] Bienzle D, Silverstein DC, Chaffin K. Multiple Myeloma in Cats: Variable Presentation and Different Immunoglobin Isotypes in Two Cats. Veterinary Pathology 2000;37(4) 364-369. 
[3] Pusterla N, Stacy BA, Vernaw W, De Cock HEV, Magdesian KG. Immunoglobulin A Monoclonal Gammopathy in Two Horses with Multiple Myeloma. Veterinary Record 2004;155(1) 19-23.

[4] Patel RT, Caceres A, French AF, McManus M. Multiple Myeloma in 16 Cats: a Retrospective Study. Veterinary Clinical Pathology 2005;34(4)341-352.

[5] Thrall MA. Lymphoproliferative Disorders. Lymphocytic Leukemia and Plasma Cell Myeloma. Veterinary Clinics of North America: Small Animal Practice 1981;11 321-347.

[6] Geelen SN, Bernardina WE, Grinwis GC, Kalsbeek HC. Monoclonal Gammopathy in a Dutch Warmblood Mare. Veterinary Quarterly 1997;19(1) 29-32.

[7] McConkey S, Lopez A, Pringle J. Extramedullary Plasmacytoma in a Horse with Ptyalism and Dysphagia. Journal of Veterinary Diagnostic Investigation 2000;12(3) 282-284.

[8] Barton MH, Sharma P, LeRoy B, Howerth EW. Hypercalcemia and High Serum Parathyroid Hormone-Related Protein Concentration in a Horse with Multiple Myeloma. Journal of American Veterinary Medical Association 2004;225(3) 409-413.

[9] Facchini RV, Bertazzolo W, Zuliani D, Bonfanti U, Caldin M, Avalline G, Roccabianca P. Detection of Biclonal Gammopathy by Capillary Zone Electrophoresis in a Cat and a Dog with Plasma Cell Neoplasia. Veterinary Clinical Pathology 2010;39(4) 440-446.

[10] Seelig DM, Perry JA, Avery AC, Avery PR. Monoclonal Gammopathy without Hyperglobulinemia in 2 Dogs with IgA Secretory Neoplasms. Veterinary Clinical Pathology 2010;39(4) 447-453.

[11] Jacobs T. Multiple Myeloma in a Cat with Paraparesis. Feline Practice 1994;22(4) 28-32.

[12] McDonald WJ, Burton SA, Fuentealba IC. Plasma Cell Myeloma Producing an Immunoglobulin A Paraprotein in a Cat. Canadian Veterinary Journal 1994;35(3) 157.

[13] Weber NA, Tebeau CS. An Unusual presentation of Multiple Myeloma in Two Cats. Journal of American Animal Hospital Association 1998;34(6) 477-483.

[14] King AJ, Davies DR, Irin PJ. Feline Multiple Myeloma: Literature Review and Four Case Reports. Australian Veterinary Practice 2002;32 146-151.

[15] Zeugswetter F, Kleiter M, Wolfesberger B, Schwendenwen I, Miller I. Elevated Fructosamine Concentrations Caused by IgA Paraproteinemia in Two Dogs. Journal of Veterinary Science 2010;11(4) 359-361.

[16] Fukumoto S, Hanazono K, Kawasaki N, Hori Y, Higuchi S, Sasaki T, Temma K, Uchide T. Anaplastic Atypical Myeloma with Extensive Cutaneous Involvement in a Dog. Journal of Veterinary Medical Science 2012;74(1) 111-115. 
[17] Weiss DJ. A Retrospective Study of the Incidence and the Classification of Bone Marrow Disorders in the Dog at a Veterinary Teaching Hospital (1996-2004). Journal of Veterinary Internal Medicine 2006;20(4) 955-961.

[18] Kim DY, Taylor HW, Eades SC, Cho DY. Systemic AL Amyloidosis Associated with Multiple Myeloma in a Horse. Veterinary Pathology 2005;42(1) 81-84.

[19] Kato H, Momoi Y, Omori K, Youn HY, Yamada T, Goto N, Ono K, Watari T, Tsujimoto H, Hasegawa A. Gammopathy with Two M-Components in a Dog with IgType Multiple Myeloma. Veterinary Immunology and Immunopathology 1995;49(1-2) 161-168.

[20] Marks SL, Moore PF, Taylor DW, Munn RJ. Nonsecretory Multiple Myeloma in a Dog: Immunohistologic and Ultrastructural Observations. Journal of Veterinary Internal Medicine 1995;9(1) 50-54.

[21] Peterson EN, Meininger AC. Immunoglobulin A and Immunoglobulin G Biclonal Gammopathy in a Dog with Multiple Myeloma. Journal of American Animal Hospital Association 1997;33(1) 45-47.

[22] Villiers E, Dobson J. Multiple Myeloma with Associated Polyneuropathy in a German Shepherd Dog. Journal of Small Animal Practice 1998;39(5) 249-251.

[23] Ramaiah SK, Seguin MA, Carwile HE, Raskin RE. Biclonal Gammopathy Associated with Immunoglobulin A in a Dog with Multiple Myeloma. Veterinary Clinical Pathology 2002;31(2) 83-89.

[24] Mayer MN, Kerr ME, Grier CK, McDonald VS. Immunoglobulin A Multiple Myeloma with Cutaneous Involvement in a Dog. Canadian Veterinary Journal 2008;49(7) 694-702.

[25] Tripp CD, Bryan JN, Wills TB. Presumptive Increase in Protein-Bound Serum Calcium in a Dog with Multiple Myeloma. Veterinary Clinical Pathology 2009;38(1) 87-90.

[26] Lautzenhiser SJ, Walker MC, Goring RL. Unusual IgM-Secreting Multiple Myeloma in a Dog. Journal of American Veterinary Medical Association 2003;223(5),645-648.

[27] Matus RE, Leifer CE, MacEwen EG, Hurvitz AI. Prognostic Factors for Multiple Myeloma in the Dog. Journal of American Veterinary Medical Association 1986;188(11) 1288-1292.

[28] Hickford FM, Stokol T, Van Gessel YA, Randolph JF, Schermerhorn T. Monoclonal Immunoglobulin G Cryoglobulinemia and Multiple Myeloma in a Domestic Shorthair Cat. Journal of Veterinary Medical Science 2000;217(7) 1029-1033.

[29] Hanna F. Multiple Myelomas in Cats. Journal of Feline Medicine and Surgery 2005;7(5) 278-287.

[30] Yamada O, Tamura K, Yagihara H, Isotani M, Azakami M, Sawada S, Ono K, Washizu T, Bankobara M. Light-Chain Multiple Myeloma in a Cat. Journal of Veterinary Diagnostic Investigation 2007;19(4) 443-447. 
[31] Appel SL, Moens NM, Abrams-Ogg A, Woods JP, Nykamp S, Bienzle D. Multiple Myeloma with Central Nervous System Involvement in a Cat. Journal of American Veterinary Medical Association 2008;233(5) 743-747.

[32] Webb J, Chary P, Morthrup N, Almy F. Erythrophagocytic Multiple Myeloma in a Cat. Veterinary Clinical Pathology 2008;37(3) 302-307.

[33] Takeuchi Y, Iizuko H, Kanemitsu H, Fujino Y, Nakashima K, Uchida K, Ohno K, Nakayama H, Tsugimoto H. Myeloma-Related Disorder with Leukaemic Progression in a Cat. Journal of Feline Medicine and Surgery 2010;12(12) 982-987.

[34] Williams DH, Goldschmidt MH. Hyperviscosity Syndrome with IgM Monoclonal Gammopathy and Hepatic Plasmacytoid Lymphosarcoma in a Cat. Journal of Small Animal Practice 1982;23(6) 311-323.

[35] Kyle RA, Gertz MA, Witzig TE. Review of 1027 Patients with Newly Diagnosed Multiple Myeloma. Mayo Clinic Proceedings 2003;78(1) 21-33.

[36] McAllister C, Quall C, Tyler R, Root CR. Multiple Myeloma in a Horse. Journal of American Veterinary Medical Association 1987;191(3) 337-339.

[37] Henry M, Prasse K, White S. Hemorrhagic Diathesis Caused by Multiple Myeloma in a Thee-Month-Old Foal. Journal of American Veterinary Medical Association 1989;194(3) 392-394.

[38] Wing S, Richarson D, Wolf S, Mihlan G, Crawford-Brown D, Wood J. A Case Control Study of Multiple Myeloma at Four Nuclear Facilities. Annual Epidemiology 2000;10(3) 144-153.

[39] Morgan GJ, Davies FE, Linet M. Myeloma Aetiology and Epidemiology. Biomedical Pharmacotherapy 2002;56(5) 223-234.

[40] Yiin JK, Anderson JL, Daniels RD, Seel EA, Fleming DA, Waters KM, Chen PH. A Nested Case-Control Study of Multiple Myeloma and Uranium Exposure among Workers at the Oak Ridge Gaseous Diffusion Plant. Radiation Research 2009;171(6) 637-645.

[41] Wang JX, Inskip JD, Boir JD, Li BX, Zhang JY, Fraumeni JF. Cancer Incidence among Medical Diagnostic X-ray Workers in China, 1950 to 1985. International Journal of Cancer 1990;45(5) 889-895.

[42] Boice JD, Morin NM, Glass AG, Friedman GD, Stovall M, Hoover RN, Fraumeni JF. Diagnostic X-ray procedures and Risk of Leukemia, Lymphoma and Multiple Myeloma. Journal of the American Medical Association 1991;265 1290-1294.

[43] Hatcher JL, Baris O, Olashan AF, Inskip PD, Savitz DA, Swanson GM, Pottern LM, Greenberg RS, Schwartz AG, Schoenberg JB, Brown LM. Cancer Diagnostic Radiation and the Risk of Multiple Myeloma (United States). Cancer Causes and Control 2001;12 755-761. 
[44] Grass S, Preuss KD, Ahlgrimm F, Fadle N, Regitz E, Pfoehler C, Murawski N, Pfreundschuh M. Association of a Dominantly Inherited Hyperphosphorylated Paraprotein Target with Sporadic and Familiar Multiple Myeloma and Monoclonal Gammopathy of Undetermined Significance: a Case Control Study. Lancet Oncology 2009;10(10) 950-956.

[45] Greenberg AJ, Rajkumar SV, Vachon CM. Familiar Monoclonal Gammopathy of Undetermined Significance and Multiple Myeloma: Epidemiology, Risk Factors and Biological Characteristics. Blood 2012,119(23) 5359-5366.

[46] Becker N. Epidemiology of Multiple Myeloma. Recent Results in Cancer Research 2011;183(1) 25-35.

[47] Sjak-Shie NN, Vescio RA, Berenson JR. The Role of Human Herpesvirus-8 in the Pathogenesis of Multiple Myeloma. Hematology/Oncology Clinics of North America 1999;13(6) 1159-1167.

[48] Sadeghian MH, Katebi M, Ayatollali H, Keramati MR. Immunohistochemical Study Association between Human Herpesvirus 8 and Multiple Myeloma. International Journal of Hematology 2008;88(3) 283-286.

[49] Huang B, Li J, Zhou Z, Zheng D, Liu J, Chen M. High Prevalence of Hepatitis B Virus Infection in Multiple Myeloma. Leukemia and Lymphoma 2012;53(2) 270-274.

[50] Pinato DJ, Rossi D, Minh MT, Toniutto P, Boccato E, Minisini R, Gaidano G, Pirisi M. Hepatitis B Virus and Lymphomagenesis. Novel Insights into an Occult Relationship. Digestive and Liver Diseases 2012;44(3) 235-238.

[51] Cangul IT, Wunen M, Van Garderen E, Van den Ingh TS. Clinico-Pathological Aspects of Canine Cutaneous and Mucocutaneous Plasmacytomas. Journal of Veterinary Medicine A 2002;49(6),307-312.

[52] Burnett RC, Blake MK, Thompson LJ, Avery PR, Avery AC. Evolution of a B-cell Lymphoma to Multiple Myeloma after Chemotherapy. Journal of Veterinary Internal Medicine 2004;18(5) 768-771.

[53] Radhakrishnan A, Risbon RE, Patel RT, Ruiz B, Clifford CA. Progression of a Solitary Malignant Cutaneous Plasma Cell Tumor to Multiple Myeloma in a Cat. Veterinary Comparative Oncology 2004;2(1) 36-42.

[54] Boyle TG, Holowaychuk MK, Adams AK, Marks SL. Treatment of Three Cats with Hyperviscosity Syndrome and Congestive Heart Failure Using Plasmapheresis. Journal of American Animal Hospital Association 2001;47(1) 50-55.

[55] Paradisi F, Corti G, Cinelli R. Infectious in Multiple Myeloma. Infectious Diseases. Clinics of North America 2001;15(vii-viii) 373-384.

[56] Waldman TA, Broder S, Krakauer R, Durm M, Goldman c, Meade B. The Role of Suppresor Cells in the Pathogenesis of Common Variable Hypogammaglobulinemia 
and the Immunodeficiency Associated with Myeloma. Federation Proceedings 1976;35(9) 2067-2072.

[57] Pilarski LM, Andrews FJ, Mant MJ, Ruether BA. Humoral Immune Deficiency in Multiple Myeloma Patients due to Compromised B Cell Function. Journal of Clinical Immunology 1986;6(6) 491-501.

[58] Dammacco F, Miglietta A, Bonomo L. Immune Functions in Patients with Multiple Myeloma (Delayed Cutaneous Reactivity and Lymphocytes Bearing Receptors for Sheep, Human and Mouse Erythrocytes). International Journal of Clinical and Laboratorial Research 1977;7 343-353.

[59] Jacobson DR, Zolla-Pazner S. Immunosuppresion and Infection in Multiple Myeloma. Seminars in Oncology 1986;13(3) 282-290.

[60] Schalm OW, Knight HD, Osburn BR. Idiopathic Gammopathy and Plasmacytosis in a Horse. California Veterinarian 1974;28 13-20.

[61] Drake MT. Bone Disease in Multiple Myeloma. Oncology (Williston Park) 2009;23(14) 28-32.

[62] Minter AR, Simpson H, Weiss BM, Landgren O. Bone Disease from Monoclonal Gammopathy of Undetermined Significance to Multiple Myeloma: Pathogenesis, Interventions and Future Opportunities. Seminars in Hematology 2011;48(1) 55-65.

[63] Drew RA, Greatorex JC. Vertebral Plasma Cell Myeloma Causing Posterior Paralysis in a Horse. Equine Veterinary Journal 1974;6(3) 131-134.

[64] MacEwen EG, Hurvitz AI. Diagnosis and Management of Monoclonal Gammopathies. Veterinary Clinics of North America 1977;7(1) 119-132.

[65] Sheafor SE, Gamblin RM, Couto CG. Hypercalcemia in Two Cats with Multiple Myeloma. Journal of American Animal Hospital Association 1982;18 79-82.

[66] Eastman CA. Plasma Cell Tumors in a Cat. Feline Practice 1990;24(1) 26-31.

[67] Rosol TJ, Tannehill-Gregg SH, LeRoy BE, Mandl S, Contag CH. Animal Models of Bone Metastasis. Cancer 2003;97(3) 748-757.

[68] McMannus PM, Wood AKW, Christiansen JS, Craig LE. Lytic Lesion in the Distal Humerus of a Dog. Veterinary Clinical Pathology 2001;30(3) 121-123.

[69] Biller DS, Johnson GC, Birchard SJ, Fingland RB. Aneurysmal Bone Cyst in a Rib of a Cat. Journal of American Veterinary Medical Association 1987;190(9) 1193-1195.

[70] Pernell RT, Dunstan RW, DeCamp CE. Aneurysmal Bone Cyst in a Six-Month-Old Dog. Journal of American Veterinary Medical Association 1992;201(12) 1897-1899.

[71] Miura N, Fujiki M, Miyoshi Y, Misumi K, Sakamoto H. Steroid Injection Therapy in a Feline Solitary Bone Cyst. Journal of Veterinary Medical Science 2003;65(4) 523-525. 
[72] Shimada A, Yanagida M, Umemura T, Tsukamoto S, Suganuma T. Aneurysmal Bone Cyst in a Dog. Journal of Veterinary Medical Science 1996;58(10) 1037-1038.

[73] Simon D, Gruber AD, Hewicker-Trautwern M, Nolte I. Pathological Femoral Fracture due to a Rhabdomyosarcoma in a Cat. Journal of Small Animal Practice 2000;41(12) 566-570.

[74] Norrdin RW, Moffat KS, Thrall MA, Gasper PW. Characterization of Osteopenia in Feline Mucopolysaccharidosis VI and Evaluation of Bone Marrow Transplantation Therapy. Bone 1993;14 361-367.

[75] Henik RA, Forrest LJ, Friedman AL. Ricketts Caused by Excessive Renal Phosphate Loss and Apparent Abnormal Vitamin D Metabolism in a Cat. Journal of American Veterinary Medical Association 1999;215(11) 1620-1621.

[76] Tomsa K, Glauss T, Hauser B. Nutritional Secondary Hyperparathyroidism in Six Cats. Journal of Small Animal Practice 1999;40(11) 533-539.

[77] Schwarz T, Stork CK, Mellor D, Sullivan M. Osteopenia and other Radiographic Signs in Canine Hyperadrenocorticismo. Journal of Small Animal Practice 2000;41(11) 491-495.

[78] Kyle RA. Multiple Myeloma: Review of 869 Cases. Mayo Clinic Proceedings 1975;50(1) 29-40.

[79] Kapadia SB. Multiple Myeloma: A Clinicopathologic Study of 62 Consecutively Autopsied Cases. Seminar in Oncology 1986;13 282-290.

[80] Saif MW, Allegra CJ, Greenberg B. Bleeding Diathesis in Multiple Myeloma. Journal of Hemotherapy and Stem Cell Research 2001;10(5) 657-660.

[81] Castelli R, Ferrari B, Cortelezzi A, Guariglia A. Thromboembolic Complications in Malignant Haematological Disorders. Current Vascular Pharmacology 2010;8(4) 482-494.

[82] Coppola A, Tufano A, Di Capua M, Franchini M. Bleeding and Thrombosis in Multiple Myeloma and Related Plasma Cell Disorders. Seminars in Thrombosis and Hemostasis 2011;37(8) 929-945.

[83] Gentilini F, Calzolan C, Buonacucina A, Di Tommaso H, Militerno G, Famigli P, Bergamini P. Different Biological Behaviour of Waldenström Macroglobulinemia in Two Dogs. Veterinary Comparative Oncology 2005;3(2) 87-97.

[84] Hendrix DV, Gelatt KN, Smith PJ, Brooks DE, Whittaker CJ, Chmielewski NT. Ophtalmic Disease as the Presenting Complaint in Five Dogs with Multiple Myeloma. Journal of American Animal Hospital Association 1998;34(2) 121-128.

[85] Forrester SD, Greco DS, Relford RL. Serum Hyperviscosity Syndrome Associated with Multiple Myeloma in Two Cats. Journal of American Veterinary Medical Association 1992;200(1) 79-82. 
[86] Jacobs RM, Kociba GJ, Ruoff WW. Monoclonal Gammopathy in a Horse with Defective Hemostasis. Veterinary Pathology 1983;20 643-647.

[87] Silberstein LE, Duggan D, Berkman EM. Therapeutic Trial of Plasma Exchange in Osteosclerotic Myeloma Associated with the POEMS Syndrome. Journal of Clinical Apheresis 1985;2(3) 253-257.

[88] Knudsen LM, Hjorth M. Hippe E. Renal Failure in Multiple Myeloma: Reversibility and Impact on the Prognosis. European Journal of Haematology 2000;65(3) 175-181.

[89] Clark AD, Shetty A, Soutar R. Renal Failure and Multiple Myeloma: Pathogenesis and Treatment of Renal Failure and Management of Underlying Myeloma. Blood Reviews 2002;13(2) 119-198.

[90] Dimopoulos MA, Kastritis E, Rosinol L, Bladé J, Ludwig H. Pathogenesis and Treatment of Renal Failure in Multiple Myeloma. Leukemia 2008;22 1485-1493.

[91] Batuman V. Drersbach AW, Cyran J. Light-Chain Binding Sites on Renal Brush Border Membranes. American Journal of Physiology 1990;258(5) F1259-F1265.

[92] Batuman V, Guan S. Receptor-Mediated Endocytosis of Immunoglobulin Light Chains by Renal Proximal Tubular Cells. American Journal of Physiology 1997;272(4) F521-F530.

[93] Batuman V, Verroust PJ, Navar GL, Kaysen JH, Godo FO, Campbell WC, Simon E, Pontillon F, Lyles M, Bruno J, Hammond TC. Myeloma Light Chains are Ligands for Cubilin (pg280). American Journal of Physiology 1998;275(2) F246-F254.

[94] Santosfetano M, Zanchelli F, Zaccaria A, Poletti G, Fusaroli M. The Ultrastructural Basis of Renal Pathology in Monoclonal Gammopathies. Journal of Nephrology 2005;18(6) 659-675.

[95] Huang ZQ, Sanders PW. Biochemical Interaction between Tamm-Horsfall Glycoprotein and Ig Light Chains in the Pathogenesis of Cast Nephropathy. Laboratory Investigation 1995;73(6) 810-817.

[96] Huang ZQ, Saunders PW. Localization of a Single Binding Site for Immunoglobulin Light Chains on Human Tamm-Horsfall Glycoprotein. Journal of Clinical Investigation 1997;99 (4)732-736.

[97] Ying WZ, Sanders PW. Mapping the Binding Domain of Immunoglobin Light Chains for Tamm-Horsfall Protein. American Journal of Pathology 2001;158(5) 1859-1866.

[98] Sanders PW, Booker BB, Bishop JB, Cheung HC. Mechanisms of Intranephronal Proteinaceous Cast Formation by Low Molecular Weight Proteins. Journal of Clinical Investigation 1990;85(2) 570-576.

[99] Sanders PW, Booker BB. Pathobiology of Cast Nephropathy from Human BenceJones Proteins. Journal of Clinical Investigation 1992; 89(2) 630-639. 
[100] Solomon A, Weiss DT, Kattine AA. Nephrotoxic Potential of Bence-Jones Proteins. New England Journal of Medicine 1991;324(26) 1845-1851.

[101] Batuman V. Proximal Tubular Injury in Myeloma. Contributions in Nephrology 2007; 153 87-104.

[102] Comenzo RL, Zhang Y, Martinez C, Osman K, Herrera GA. The Tropism of Organ Involvement in Primary Systemic Amyloidosis: Contributions of $\operatorname{IgV}(\mathrm{L}) \mathrm{Germ}$ Line Gene Use and Clonal Plasma Burden. Blood 2001;98(3) 714-720.

[103] Keeling J, Herrera GA. The Mesangium as a Target for Glomerulopathic Light and Heavy Chains: Pathogenic Considerations in Light and Heavy Chain-Mediated Glomerular Damage. Contributions in Nephrology 2007;153 116-134.

[104] Sanders DW, Herrera GA, Galla JH. Human Bence-Jones Protein Toxicity in Rat Proximal Tubular Epithelium in vivo. Kidney International 1987;32(6) 851-861.

[105] Ma CX, Locy MQ, Rompala JF, Dispenzier A, Rajkumar SV, Greipp PR, Fonseca R, Kyle RA, Gertz MA. Acquired Fanconi Syndrome is an Indolent Disorder in the Absence of Overt Multiple Myeloma. Blood 2004;104(1) 40-42.

[106] Savary KC, Price GS, Vaden SL. Hypercalcemia in Cats: A Retrospective Study of 71 Cases (1991-1997). Journal of Veterinary Internal Medicine 2000;14(2) 184-189.

[107] Kogika MM, Lustoza MD, Notomi MK, Wirthl VA, Mirandola RH, Hagiwara MK. Serum Ionized Calcium in Dogs with Chronic Renal Failure and Metabolic Acidosis. Veterinary Clinical Pathology 2006;35(4) 441-445.

[108] Messenger JS, Windham WR, Ward CR. Ionized Hypercalcemia in Dogs: A Retrospective Study of 109 Cases (1998-2003). Journal of Veterinary Internal Medicine 2009;23(3) 514-519.

[109] Woldemeskel M. A Concise Review of Amyloidosis in Animals. Veterinary Medicine International 2012;2012:427296. Epub 2012, Mar 15

[110] Escorsell A, López-Guillermo A, Blade J, Villamor N, Massanes F, Montserrat G, Rozman C. Meningeal Infiltration in Multiple Myeloma. Study of a New Case and Literature Review. Revista Clínica Española 1992;191(9) 479-480.

[111] Schluterman KO, Fassas AB, Van Hemert RL, Hank SI. Multiple Myeloma Invasion of the Central Nervous System. Archives of Neurology 2004;61(9) 1423-1429.

[112] Vermeiren P, Vantilborgh A, Offmer F. Myeloma of the Central Nervous System: Report of a Single Center Case Series. Acta Clinica Belgica 2011;66(3) 205-208.

[113] Marjanovic S, Mijuskovic Z, Stamatovic D, Madjaro L, Ralic T, Trimceu J, Stojanovic J, Radovic V $2^{\text {nd }}$. Multiple Myeloma Invasion of the Central Nervous System. Vojnosanitetski Pregled. Military Medical and Pharmaceutical Review 2012;69(2) 209-213. 
[114] Braund KG, Everett M, Bartels E, DeBysscher E. Neurologic Complications of IgA Multiple Myeloma Associated with Cryoglobulinemia in a Dog. Journal of American Veterinary Medical Association 1979;174(12) 1321-1325.

[115] Van Bree H, Pollet L, Cousement W, Van der Stock J, Mattheeuws D. Cervical Cord Compression as a Neurologic Complication of an IgG Multiple Myeloma in a Dog. Journal of American Animal Hospital Association 1983;19 317-323.

[116] Hammer AS, Couto CG. Complications of Multiple Myeloma. Journal of American Animal Hospital Association 1994;30 9-14.

[117] Malhotra P, Choudhary PP, Lal V, Varma N, Suri V, Varma S. Prevalence of Peripheral Neuropathy in Multiple Myeloma at Initial Diagnosis. Leukemia and Lymphoma 2011;52(11) 2135-2138.

[118] Drappatz J, Batchelor T. Neurologic Complications of Plasma Cell Disorders. Clinical Lymphoma 2004;5(3) 163-171.

[119] Dispenzieri A, Kyle RA. Neurological Aspects of Multiple Myeloma and Related Disorders. Best Practice and Research. Clinical Haematology 2005;18(4) 673-688.

[120] Dernier C, Lozeron P, Adams D, Decaudin D, Isnard-Grivaux F, Lacroix C, Said D. Multifocal Neuropathy due to Plasma Cell Infiltration of Peripheral Nerves in Multiple Myeloma. Neurology 2006;66(6) 917-918.

[121] Bosch EP, Smith BE. Peripheral Neuropathies Associated with Monoclonal Proteins. Medicine Clinics of North America 1993;77(1) 125-139.

[122] Gherardi RK, Authier FJ, Belec L. Pro-Inflammatory Cytokines: A Pathogenic Key of POEMS Syndrome. Review of Neurology (Paris) 1996;152(5) 409-412.

[123] Gherardi RK, Chrétien F, Delfau-Larue MH, Authier FJ, Moulignier A, RoullandDussoix D, Bélec L. Neurophaty in Diffuse Infiltrative Lymphocytosis Syndrome: An HIV Neuropathy, not a Lymphoma. Neurology 1998;50(4) 1041-1044.

[124] Ravaglia S, Corso A, Piccolo G, Lozza A, Alfonsi E, Mangiacavalli S, Varettoni M, Zappasodi P, Moglia A, Lazzarino M, Costa A. Immune-Mediated Neuropathies in Myeloma Patients Treated with Bortezomib. Clinical Neurophysiology 2008;119(11) 2507-2512.

[125] Cavaletti G, Gilardini A, Canta A, Rigamonti L, Rodríguez-Menéndez V, Ceresa C, Marmiroli P, Bossi M, Oggioni N, D'Incalci M, De Coster, R. Bortezomib-Induced Peripheral Neurotoxicity: a Neurophysiological and Pathological Study in the Rat. Experimental Neurology 2007;204(1) 317-325.

[126] Mohty B, El-Cheikh J, Yakoub-Agha I, Moreau P, Harousseau JL, Mothy M. Peripheral Neuropathy and New Treatments for Multiple Myeloma Background and Practical Recommendations. Haematologica 2010;95(2) 311-319.

[127] Braund KG. Endogenous Causes of Neuropathies in Dogs and Cats. Veterinary Medicine 1996;91 740-754. 
[128] Mariani CL, Shelton SB, Alsup JC. Paraneoplastic Polyneuropathy and Subsequent Recovery Following Tumor Renoval in a Dog. Journal of American Animal Hospital Association 1999;35(4) 302-305.

[129] Cavana P, Sammartano F, Capucchio MT, Catalano D, Valazza A, Farca AM. Peripheral Neuropathy in a Cat with Renal Lymphoma. Journal of Feline Medicine and Surgery 2009;11(10) 869-872.

[130] Mittelman M. The Implications of Anemia in Multiple Myeloma. Clinical Lymphoma 2003;4(1) S23-S29.

[131] Ludwig H, Pohl G, Osterborg A. Anemia in Multiple Myeloma. Clinical Advances in Hematology and Oncology 2004;2(4) 233-241.

[132] Laubach, J. Richardson P, Anderson K. Multiple Myeloma. Annual Review of Medicine 2011;62 249-264.

[133] Madewell BR, Munn RJ, Phillips LP. Endocytosis of Erythrocytes in Vivo and Particulate Substances in Vitro by Feline Neoplastic Mast Cells. Canadian Journal of Veterinary Research 1987;51(4) 517-520.

[134] Darbes J, Majzoub M, Breuer W, Hermanns W. Large Granular Lymphocyte Leukemia/Lymphoma in Six Cats. Veterinary Pathology 1998;35(5) 370-379.

[135] Ezura K, Ezura K, Nomura I, Takahashi T, Shibahara T. Natural Killer-Like T Cell Lymphoma in a Cat. Veterinary Record 2004;154(9) 268-270.

[136] Court EA, Earnest-Koons KA, Barr SC, Gould WI II. Malignant Histiocytosis in a Cat. Journal of American Veterinary Medical Association 1993;203 1300-1302.

[137] Savage DG, Zipin D, Bhagat G, Aloberd B. Hemophagocytic Non-Secretory Multiple Myeloma. Leukemia and Lymphoma 2004;45(5) 1061-1064.

[138] Kanoh T, Fujii H. Phagocytic Myeloma Cells: Report of a Case and Review of the Literature. American Journal of Clinical Pathology 1985;84(1) 121-124.

[139] Kucukkaya RD, Hacihanefioghi A, Yenerei MN, Turgut M, Nalcaci M, Keskin H. CD15-Expressing Phagocytic Plasma Cells in a Patient with Multiple Myeloma. Blood 2001;97(2) 581-582.

[140] San Miguel FJ, Sanchez J, Gonzalez M. Prognostic Factors and Classification of Multiple Myeloma. British Journal of Cancer 1989;59(1) 113-118.

[141] Caro JJ, Salas M, Ward A, Goss G. Anemia as an Independent Prognostic Factor For Survival in Patients with Cancer. Cancer 2001;91(12) 2214-2221.

[142] Fritz E, Ludwig H, Scheithauer W, Sinzinger. Shortened Platelet Half-Life in Multiple Myeloma. Blood 1986;68(2) 514-520.

[143] Falanga A, Rickles FR. Management of Thrombohemorrhagic Syndromes (THS) in Hematologic Malignancies. American Society of Hematology Education Program 2007;2007(1) 165-171. 
[144] Chen YH, Marganda MD, Magalhaes C. Hypoalbuminemia in Patients with Multiple Myeloma. Archives of Internal Medicine 1990;150(3) 605-610.

[145] Bataille R, Jourdan H, Zhang XG, Klein B. Serum Levels of Interleukin G, A Potent Myeloma Cell Growth Factor, as a Reflect of Disease Severity in Plasma Cell Dyscrasias. Journal of Clinical Investigation 1989;84(6) 2008-2011.

[146] Lichtenstein A, Tu Y, Fady C, Vescio R, Berenson J. Interleukin-6 Inhibits Apoptosis of Malignant Plasma Cells. Cellular Immunology 1995;162(2) 248-255.

[147] Lim JE, Yoo C, Lee DM, Kim SW, Lee JJ, Suh C. Serum Albumin Level is a Significant Prognostic Factor Reflecting Disease Severity in Symptomatic Multiple Myeloma. Annals of Hematology 2010;89(4) 391-397.

[148] Kyle RA, Greipp RPR. The Laboratory Investigation of Monoclonal Gammopathies. Mayo Clinic Proceedings 1978;53(11) 719-739.

[149] Giraudel JM, Pagés JP, Guelfi JF. Monoclonal Gammopathies in the Dog: A Retrospective Study of 18 cases (1986-1999) and Literature Review. Journal of American Animal Hospital Association 2002;38(2) 135-147.

[150] Harrus W, Waner T, Avidar Y, Bogin E, Peh H, Bark H. Serum Protein Alterations in Canine Ehrlichiosis. Veterinary Parasitology 1996;66(3-4) 241-249.

[151] Taylor SS, Tappin SW, Dodkin SJ, Papasouliotis K, Casamian-Sorrosal D, Tasker S. Serum Protein Electrophoresis in 155 Cats. Journal of Feline Medicine and Surgery 2010;12(8) 643-653.

[152] Tappin SW, Taylor SS, Tasker S, Dodkin SJ, Papasouliotis K, Murphy KF. Serum Protein Electrophoresis in 147 Cats. Veterinary Record 2011;168(17) 456. Epub 2011.

[153] Font A, Closa JM, Mascort J. Monoclonal Gammopathy in a Dog with Visceral Leishmaniasis. Journal of Veterinary Internal Medicine 1994;8(3) 233-235.

[154] Burkhard MJ, Meyer DJ, Rosychuk RA, O'Neil SP, Schultheiss PC. Monoclonal Gammopathy in a Dog with Chronic Pyoderma. Journal of Veterinary Medicine 1995;9(5) 357-360.

[155] De Caprariis D, Sasanelli M, Paradies P, Otranto D, Lia R. Monoclonal Gammopathy Associated with Heartworm Disease of a Dog. Journal of American Animal Hospital Association 2009;45(6) 296-300.

[156] Schwartzman RM. Cutaneous Amyloidosis Associated with a Monoclonal Gammopathy in a Dog. Journal of American Veterinary Medical Association 1984;185(1) 102-104.

[157] Brown G. A Monoclonal Gammopathy-Induced Canine Renal Amyloidosis. Canadian Veterinary Journal 1996;37(2) 105. 
[158] Yamada T, Ogura A, Inoue J, Tsujimoto H, Ono K, Goto N, Tomoda I, Fujiwara K, Usui K. A Case of Feline Macroglobulinemia. Japanese Journal of Veterinary Science 1983;45(3) 395-399.

[159] Jaillardon L, Fournell-Fleury C. Waldenström's Macroglobulinemia in a Dog with a Bleeding Diathesis. Veterinary Clinical Pathology 2011;40(3) 351-355.

[160] Hoenig H, O’Brien JA. A Benign Hypergammaglobulinemia Mimicking Plasma Cells Myeloma. Journal of American Animal Hospital Association 1988;24 688-690.

[161] Kyle RA, Raijumar SV. Monoclonal Gammopathies of Undetermined Significance. Hematology and Oncology. Clinics of North America 1999;13 1181-1202.

[162] Kyle RA, Therneau TM, Rajkumar SV, Offord JR, Larson DR, Plavak MF, Melton $3^{\text {rd }}$ J. A Long-Term Study of Prognosis in Monoclonal Gammopathy in Undetermined Significance (comment). New England Journal of Medicine 2002;346 564-669.

[163] Vaerman JP, Fudenberg HH, Vaerman C, Mandy WJ. On the Significance of the Heterogeneity in Molecular Size of Human Serum $\gamma$ A Globulins. Immunochemistry 1965a;2(3) 263-272.

[164] Vaerman JP, Johnson LB, Mandy W, Fudenberg HH. Multiple Myeloma with Two Paraprotein Peaks: An Instructive Case: An Instructive Case. Journal of Laboratory Clinical Medicine 1965b;65 18-25.

[165] Rudders RA, Yakulis V, Heller P. Double Myeloma. American Journal of Medicine 1973;55(2) 215-221.

[166] Kyle RA, Robinson RA, Katzmann JA. The Clinical Aspects of Biclonal Gammopathies. American Journal of Medicine 1981;71(6) 999-1008.

[167] Jacobs RM, Couto CG, Wellman RL. Biclonal Gammopathy in a Dog with Multiple Myeloma and Cutaneous Lymphoma. Veterinary Pathology 1986;23(2) 211-213.

[168] Larsen AE, Carpenter JL. Hepatic Plasmacytoma and Biclonal Gammopathy in a Cat. Journal of American Veterinary Medical Association 1994;205(5) 708-710.

[169] Riches PG, Hobb JR. Mechanisms in Secondary Hypogammaglobulinemia. Journal of Clinical Pathology 1997;13 15-22.

[170] Kyle RA. Sequence of Testing for Monoclonal Gammopathies. Archives of Pathology- Laboratory Medicine 1999;123(2) 114-118.

[171] Wang H, Gao C, Xu L, Yang Z, Zhao W, Kong X. Laboratory Characterizations on 2007 Cases of Monoclonal Gammopathies in East China. Cellular and Molecular Immunology 2008;5(4) 293-298.

[172] O'Connell TX, Horita TJ, Kastavi B. Understanding and Interpreting Serum Protein Electrophoresis. American Family Physician 2005;71(1) 105-112. 
[173] Serra MM, Mant MJ, Ruether Ba, Ledbetter JA, Pilarski LM. Selective Loss of CD4+ CD45+ T Cells in Peripheral Blood of Multiple Myeloma Patients. Journal of Clinical Immunology 1988;8 259-265.

[174] Walchner M, Wick M. Elevations of CD8+ CD11b+ Leu-8- T Cells is Associated with the Humoral Immunodeficiency in Myeloma Patients. Clinical and Experimental Immunology 1997;109(2) 310-316.

[175] Kluger N, Sirvente J, Rigau V, Guillot B. Extensive Thrombotic Purpura Revealing Multiple Myeloma Associated Type 1 Cryoglobulinemia. British Journal of Haematology 2011;154(1) Epub 2011.

[176] Payet J, Livartowski H, Kavian N, Chndesris O, Duplin N, Wallet N, Karras A, Salliot C, Suárez F, Avet-Loiseau H, Alyanakian MA, Nawakill CA, Park S, Tamburini J. Roux C, Bouscary D, Sparsa L. Type I Cryoglobulinemia in Multiple Myeloma, a Rare Entity: Analysis of Clinical and Biological Characteristics of Seven Cases and Review of the Literature. Leukemia and Lymphoma 2012;Apr. 19 (Epub ahead of print).

[177] Kallemuchikkal U, Gorevic PD. Evaluation of Cryoglobulins. Archives of Pathology and Laboratory Medicine 1999;123(2) 119-125.

[178] Virella G, Slappendel RJ, Goudswaard J. Multiple Myeloma IgA Cryoglobulinemia and Serum Hyperviscosity in a Dog. International Archives of Allergy and Applied Immunology 1977;55 537-541.

[179] Hurvitz AI, MacEwen EG, Middaug CR. Monoclonal Cryoglobulinemia with Macroglobulinemia in a Dog. Journal of American Veterinary Medical Association 1977;170(5) 511-513.

[180] Traub-Dargatz J, Bertone A, Bennett D, Jones RL, Weingand K, Hall R, Demartini JC, Lavach JD, Roberts SM. Monoclonal Aggregating Immunoglobin Cryoglobulinemia in a Horse with Malignant Lymphoma. Equine Veterinary Journal 1985;17(6) 470-473.

[181] Sabnis SG, Gunson DE, Antonovych TT. Some Unusual Features of Mesangioproliferative Glomerulonephritis in Horses. Veterinary Pathology 1984;21(6) 574-581.

[182] Maede Y, Inaba M, Amano Y, Murase T, Goto I, Itakura C. Cryoglobulinemia in a Horse. Journal of Veterinary Medical Science 1991;53(3) 379-383.

[183] Nagata M, Nanko M, Hashimoto K. Cryglobulinaemia: A Comparison of Canine and Human Cases. Veterinary Dermatology 1998;9 277-281.

[184] Foester J. Cryoglobulins and Cryoglobulinemia. In: Lee GR, Bithell TC, Foersten J (ed). Wintrobe's Clinical Hematology. Philadelphia: Lea and Febiger; 1993. p2284-2293.

[185] Merlini G, Zorzoli I, Anesi C, Perfetti V, Marinone G. Immunochemical Characterization of the Cryoglobulins: Pathophysiologic Implications. Clinical and Experimental Rheumatology 1995;13(13) 571-573. 
[186] Oken MM. Multiple Myeloma. Medical Clinics of North America 1984;68 757-787.

[187] Mundy GR, Raisz LG, Cooper RA, Schechter GP, Salmon SE. Evidence for the Secretion of an Osteoclast Stimulating Factor in Myeloma. New England Journal of Medicine 1974;291 1041-1046.

[188] Bataille R, Manolagas SC, Berenson JR. Pathogenesis and Management of Bone Lesions in Multiple Myeloma. Hematology/Oncology Clinics of North America 1997;11(2) 349-361.

[189] Roodman GD. Pathogenesis of Myeloma Bone Disease. Leukemia 2009;23(3) 435-441.

[190] Sezer O. Mieloma Bone Disease: Recent Advances in Biology, Diagnosis and Treatment. Oncologist 2009;14(3) 276-283.

[191] Farrugia AN, Atkins GJ, Bik L, Pan B, Horvath N, Kostakis P, Findlay DM, Bardy P, Zannettino ACW. Receptor Activator of Nuclear Factor- $\kappa \mathrm{B}$ Ligand Expression by Human Myeloma Cells Mediates Osteoclast Formation In Vitro and Correlates With Bone Destruction In Vivo. Cancer Research 2003;1(63) 5431-5445.

[192] Care A, Abbas S Ousey J. The Relationship between the Concentration of Ionised Calcium and Parathyroid Hormone-Related Protein (PTHrP I-34) in Milk of Mares. Equine Veterinary Journal 1997;29 186-189.

[193] Wysolmerski J, Stewart A. The Pathophysiology of Malignancy: Diagnosis and Treatment. Compendium on Continuing Education for the Practicing Veterinarian 2003;25 129-136.

[194] Vasilopulos RJ, Mackin A. Humoral Hypercalcemia of Malignancy: Pathophysiology and Clinical Signs. Compendium on Continuing Education for the Practicing Veterinarian 2003;25(2) 122-128.

[195] Van der Kolk JH. Humoral Hypercalcaemia of Malignancy or Pseudohyperparathyroidism in the Horse. Equine Veterinary Education 2007;19(7) 384-386.

[196] Foley P, Shaw D, Runyon C, McConkay S, Ikede B. Serum Parathyroid Hormone-Related Protein Concentration in a Dog with a Thymoma and Persistent Hypercalcemia. Canadian Veterinary Journal 2000;41(11) 867-870.

[197] Anderson GM, Lane I, Fischer J, Lopez A. Hypercalcemia and Parathyroid HormoneRelated Protein in a Dog with Indifferentiated Nasal Carcinoma. Canadian Veterinary Journal 1999;40(5) 341-342.

[198] Martin CK, Tannehill-Gregg SH, Wolfe TD, Rosol TJ. Bone-Invasive Oral Squamous Cell Carcinoma in Cats: Pathology and Expression of Parathyroid Hormone-Related Protein. Veterinary Pathology 2011;48(1) 302-312.

[199] Gajanayake I, Priestnall SL, Benigni L, English K, Summers BA, Garden OA. Paraneoplastic Hypercalcemia in a Dog with Benign Renal Angiomyxoma. Journal of Veterinary Diagnostic Investigation 2010;22(5) 775-780. 
[200] Bae BK, Kim CW, Choi US, Choi EW, Jee H, Kim DY, Lee CW. Hypercalcemia and High Parathyroid Hormone-Related Peptide Concentration in a Dog with a Complex Mamary Carcinoma. Veterinary Clinical Pathology 2007;36(4) 376-378.

[201] Bollinger AP, Graham PA, Richard V, Rosol TJ, Nachreiner RF, Refsal KR. Detection of Parathyroid Hormone-Related Protein in Cats with Humoral Hypercalcemia of Malignancy. Veterinary Clinical Pathology 2002;31(1) 3-8.

[202] Kubota A, Kano R, Mizuno T, Tisasue M, Moore PF, Watari T, Tsujimoto H, Hawegawa A. Parathyroid Hormone-Related Protein (PTHrP) Produced by Dog Lymphoma Cells. Journal of Veterinary Medical Science 2002;64(9) 835-837.

[203] Mellanby RJ, Craig R, Evans H, Herrtage ME. Plasma Concentrations of Parathyroid Hormone-Related Protein in Dogs with Potential Disorders of Calcium Metabolim. Veterinary Record 2006;159(25) 833-838.

[204] Pressler BM, Rotstein DS, Law J, Rosol TJ, LeRoy B, Keene BW, Jackson MW. Hypercalcemia and High Parathyroid Hormone-Related Protein Concentration Associated with Malignant Melanoma in a Dog. Journal of American of Veterinary Medical Association 2002;221(2) 263-265.

[205] Bienzle D, Jacobs RM, Lumsden JH. Relationship of Serum Total Calcium to Serum Albumin in Dogs, Cats, Horses and Cattle. Canadian Veterinary Journal 1993;34(6) 360-364.

[206] Duncan PH, Wills MR, Smith BJ, Savory J. Clinical Studies of Protein-Bound Calcium in Various Diseases. Clinical Chemistry 1982;28(4) 672-675.

[207] Center SA, Smith JF. Ocular lesions in a Dog with Serum Hyperviscosity Secondary to an IgA Myeloma. Journal of American Veterinary Medical Association 1982;181(8) 811-813.

[208] Munshi NC, Tricot GJ, Barlogie B. Plasma Cell Neoplasms. In: DeVita VT, Hellman S, Rosenberg SA (eds.). Cancer: Principles and Practice of Oncology. $6^{\text {th }}$ Ed. Philadelphia PA: Lippincott, Williams \& Wilkins; 2001. p2465-2499.

[209] Abraham A, Shafi F, Iqbal M, Kollipara R, Rouf E. Syndrome of Inappropriate Antidiuretic Hormone due to Multiple Myeloma. Missoure Medicine 2011;108(5) 377-379.

[210] Sachs J, Bredman B. The Hyponatremia of Multiple Myeloma is True and not Pseudohyponatremia. Medical Hypotheses 2006;67(4) 839-840.

[211] Scollozi R, Boccafogli A, Salmi R, Furlani MR, Guidoboni CA, Vicentini L, Coletti M, Toccheto M. Hypocholesterolemia in Multiple Myeloma. Inverse Relation to the Component M and the Clinical Stage. Minerva Medicine 1983;74(40) 2359-2363.

[212] Yavasoglu I, Tombuloglu M, Kadikoylu G, Donmez A, Cagirgan S, Bolaman Z. Cholesterol Levels in Patients with Multiple Myeloma. Annales of Hematology 2008;87(3) 223-228. 
[213] Kimmel SE, Waddell LS, Michel KE. Hypomagnesemia and Hypocalcemia Associated with Protein-Losing Enteropathy in Yorkshire Terriers: Five cases (1992-1998). Journal of American Veterinary Medical Association 2000;217(5) 703-706.

[214] Berent AC, Drobatz KJ, Ziemer L, Johnson VS, Ward CR. Liver Function in Cats with Hyperthyroidism Before and After 131I Therapy. Journal of Veterinary Internal Medicine 2007;21(6) 1217-1223.

[215] Lecoindre P, Chevallier M, Guerret S. Protein-Losing Enteropathy of Non-Neoplastic Origin in the Dog: A Retrospective Study of 34 Cases. Schweizer Archiv für Tierheilkunde 2010;152(3) 141-146.

[216] Perry MC, Kyle RA. The clinical Significance of Bence Jones Proteinuria. Mayo Clinic Proceedings 1975;50(5) 234-238.

[217] Uchida M, Kamata K, Okubo M. Renal Dysfunction in Multiple Myeloma. Internal Medicine 1995;34(5) 364-370.

[218] Bladé J, Fernández-Llama P, Bosch F, Montoliu J, Lens XM, Montoto S, Cases A, Darnell A, Rozman C, Montserrat E. Renal Failure in Multiple Myeloma: Presenting Features and Predictors of Outcome in 94 Patients from a Single Institution. Archives of Internal Medicine 1998;158(17) 1889-1893.

[219] Cengic M, Robovic Z, Rasic S, Goleman S. Relation Between Certain Parameters of Renal Function and Prognosis in Multiple Myeloma. Medicinski Arhiv 2001;55(4) 193-195.

[220] Corso A, Zappasodi P, Lazzarino M. Urinary Proteins and Renal Dysfunction in Patients with Multiple Myeloma. Biomedicine and Pharmacotherapy 2002;56(3) 139-143.

[221] Eleutherakis-Papaiakovou V, Bamias A, Gika D, Simeonidis A, Pouli A, Anagnostopoulos A, Michali E, Economopoulos T, Zervas K, Dimopoulos MA. Renal Failure in Multiple Myeloma: Incidence, Correlations, and Prognostic Significance. Leukemia and Lymphoma 2007;48(2), 337-341.

[222] Morcos SK, El-Nahas AM, Brown P, Haylor J. Effect of Iodinated Water Soluble Contrast Media on Urinary Protein Assays. British Medical Journal 1992;305(4) 29.

[223] Grogan TM. Plasma Cell Myeloma Marrow Diagnosis Including Morphologic and Phenotypic Features. Seminars in Diagnostic Pathology 2003;20(3) 211-215.

[224] Hyun BH, Kwa D, Gabaldon H, Ashton JK. Reactive Plasmacytic Lesions of the Bone Marrow. American Journal of Clinical Pathology 1976;65(6) 921-928.

[225] Borgatti A. Plasma Cell Tumors. In: Weiss DJ, Wardrop KJ (Ed.). Schalm's Veterinary Hematology. Wiley-Blackwell: Iowa, 2010; p511-519.

[226] Ludwig H, Hajek R, Tóthová E, Drach J, Adam Z, Labar B, Egyed M, Spicka I, Gisslinger H, Greil R, Kuhn I, Zojer N, Hinke A. Thalidomide-Dexamethasone Com- 
pared with Melphalan-Prednisolone in Elderly Patients with Multiple Myeloma. Blood 2009;113(15) 3435-3442.

[227] Eom HS, Kim YK, Chung JS, Kim K, Kim HJ, Kim HY, Jin JY, Do YR, Oh SJ, Suh C, Seong CM, Kim CS, Lee DS, Lee JH. Bortezomib, Thalidomide, Dexamethasone Induction Therapy Followed by Melphalan, Prednisolone, Thalidomide Consolidation Therapy as a First Line of Treatment for Patients with Multiple Myeloma who Are Non-Transplant Candidates: Results of the Korean Multiple Myeloma Working Party (KMMWP). Annales of Hematology 2010;89(5) 489-497.

[228] Picot J, Cooper K, Bryant J, Clegg AJ. The Clinical Effectiveness and Cost-Effectiveness of Bortezomib and Thalidomide in Combination Regimens with an Alkylating Agent and a Corticosteroid for the First-Line Treatment of Multiple Myeloma: A Systematic Review and Economic Evaluation. Health Technological Assessment 2011;15(41) 1-204.

[229] Begum M, Akther A, Khan KH, Kaiser MS, Rahman MJ, Alam MN. Melphalan plus Prednisolone in the Treatment of Multiple Myeloma. Myemensigh Medical Journal 2012;21(1) 93-97.

[230] Kabir AL, Rahman MJ, Begum M, Dipta TF, Baqui MN, Aziz A, Rahman F, Debnath RC, Habib MA. Response of Vincristine, Melphalan, Cyclophosphamide and Prednisolone in Refractory Multiple Myeloma. Myemensigh Medical Journal 2012;21(1) 114-119.

[231] Lee JI, Burckart GJ. Nuclear Factor Kappa B: Important Transcription Factor and Therapeutic Target. Journal of Clinical Pharmacology 1998;38(11) 981-993.

[232] Ling J, Kumar R. Crosstalk Between NFkB and Glucocorticoid Signaling: A Potential Target of Breast Cancer Therapy. Cancer Letters 2012;322(2) 119-126.

[233] Fan TM, Kitchell BE, Dhaliwall RS. Hematological Toxicity and Therapeutic Efficacy of Lomustine in 20 Tumor-Bearing Cats: Critical Assessment of a Practical Dosing Regimen. Journal of American Animal Hospital Association 2002;38(4) 357-363.

[234] Burton JH, Mitchell L, Thamm DH, Dow SW, Biller BJ. Low-Dose Cyclophosphamide Selectively Decreases Regulatory T Cells and Inhibits Angiogenesis in Dogs with Soft Tissue Sarcoma. Journal of Veterinary Internal Medicine 2011;25(4) 920-926.

[235] Sato M, Yamazaki J, Goto-Koshina Y, Takahaski M, Fujino Y, Ohno K, Tsujimoto H. Evaluation of Cytoreductive Efficacy of Vincristine, Cyclophosphamide, and Doxorubicin in Dogs with Lymphoma by Measuring the Number of Neoplastic Lymphoid Cells with Real-Time Polymerase Chain Reaction. Journal of Veterinary Internal Medicine 2011;25(2) 285-291.

[236] Warry E, Hansen RJ, Gustafson DL, Lana SE. Pharmacokinetics of Cyclophosphamide after Oral and Intravenous Administration to Dogs with Lymphoma. Journal of Veterinary Internal Medicine 2011;25(4) 903-908. 
[237] Mitchell L, Thamm DH, Biller BJ. Clinical and Immunomodulatory Effects of Toceranib Combined with Low-Dose Cyclophosphamide in Dogs with Cancer. Journal of Veterinary Internal Medicine 2012;26(2) 355-362.

[238] Wu P, Davies FE, Horton C, Jenner MW, Krishnan B, Alvares CL, Saso R, McCormack R, Dines S, Treleaven JG, Potter MN, Ethell ME, Morgan GJ. The Combination of Cyclophosphamide, Thalidomide and Dexamethasone is an Effective Alternative to Cyclophosphamide-Vincristine-Doxorubicin-Methylprednisolone as Induction Chemotherapy prior to Autologous Transplantation for Multiple Myeloma: a Case Matched Analysis. Leukemia and Lymphoma 2006;47(11) 2335-2338.

[239] Dadacaridou M, Papanicolaou X, Maltesas D, Megalakaki C, Patos P, Panteli K, Repousis P, Mitsouli-Mentzikof C. Dexamethasone, Cyclophosphamide, Etoposide and Cisplatin (DCEP) for Relapsed or Refractory Multiple Myeloma Patients. Official Journal of Balkan Union of Oncology 2007;12(1) 41-44.

[240] Mellqvist UH, Lenhoff S, Johnsen HE, Hjorth M, Holmberg E, Juliusson G, Tangen JM, Westin J. Cyclophosphamide plus Dexamethasone is an Efficient Initial Treatment before High-Dose Melphalan and Autologous Stem Cell Transplantation in Patients with Newly Diagnosed Multiple Myeloma: Results of a Randomized Comparison with Vincristine, Doxorubicin, and Dexamethasone. Cancer 2008;112(1) 129-135.

[241] San Miguel JF, Mateos MV, Ocio E, García-Sanz R. Multiple Myeloma: Treatment Evolution. Hematology 2012;17(1) S3-S6.

[242] Flory AB, Rassnick KM, Erb HN, Garrett LD, Northrup NC, Selting KA, Phillips BS, Locke JE, Chretin JD. Evaluation of Factors Associated with Second Remission in Dogs with Lymphoma Undergoing Retreatment with a Cyclophosphamide, Doxorubicin, Vincristine, and Prednisone Chemotherapy Protocol: 95 Cases (2000-2007). Journal of American Veterinary Medical Association 2011;238(4) 501-506.

[243] Regan RC, Kaplan MS, Bailey DB. Diagnostic Evaluation and Treatment Recommendations for Dogs with Substage-A High-Grade Multicentric Lymphoma: Results of a Survey of Veterinarians. Veterinary Comparative Oncology 2012; Epub ahead of print.

[244] Mandelli F, Avvisati G, Amadori S, Boccadoro M, Gernone A, Lauta VM, Marmont F, Petrucci MT, Tribalto M, Vegna ML, Dammacco F, Pileri A. Maintenance Treatment with Recombinant Interferon Alfa-2b in Patients with Multiple Myeloma Responding to Conventional Induction Chemotherapy. New England Journal of Medicine 1990;322 1430-1434.

[245] Cunningham D, Powles R, Malpas J, Raje N, Milan S, Viner C, Montes A, Hickish T, Nicolson M, Johnson P, Treleaven J, Raymond J, Gore M. Randomized Trial of Maintenance Interferon Following High Dose Chemotherapy in Multiple Myeloma: LongTerm Follow-Up Results. British Journal of Haematology 1998;102(2) 495-502. 
[246] Attal M, Harousseau JL, Stoppa AN, Sotto JJ, Fuzibet JG, Rossi JF, Casassu P, Maisonneuve H, Facon T, Ifrah N, Payen C, Bataille R. A Prospective, Randomized Trial of Autologous Bone Marrow Transplantation and Chemotherapy in Multiple Myeloma. New England Journal of Medicine 1996;335 91-97.

[247] Gianni AM, Bregni M, Siena S, Brambilla C, Di Nicola M, Lombardi F, Gandola L, Corrado T, Pileri A, Ravagnani F, Valagussa P, Bonadonna G. High-Dose Chemotherapy and Autologous Bone Marrow Transplantation Compared with MACOP-B in Aggressive B-Cell Lymphoma. New England of Medicine 1997;336 1290-1298.

[248] Fermand JP, Ravaud P, Chevret S, Divine M, Leblond V, Belanger C, Macro M, Pertuiset E, Dreyfus F, Mariette X, Boccacio C, Brouet JC. High-Dose Therapy and Autologous Peripheral Blood Stem Cell Transplantation in Multiple Myeloma: Up-Front or Rescue Treatment?. Results of a Multicenter Sequential Randomized Clinical Trial. Blood 1998;92(9) 3131-3136.

[249] Kröger N, Schwerdtfeger R, Kiehl M, Sayer HG, Renges H, Zabelina T, Fehse B, Tögel F, Wittkowsky G, Kuse R, Zander AR. Autologous Stem Cell Transplantation Followed by a Dose-Reduced Allograft Induces High Complete Remission Rate in Multiple Myeloma. Blood 2002;100(3) 755-760.

[250] Child JA, Morgan GJ, Davies FE, Owen RG, Bell SE, Hawkins K, Brown J, Drayson MT, Selby PJ. High-Dose Chemotherapy with Hematopoietic Stem Cell Rescue for Multiple Myeloma. New England Journal of Medicine 2003;348 1875-1883.

[251] Deeg HJ, Appenlbaum FR, Weiden PL, Hackman RC, Graham TC, Storb RC. Autologous Marrow Transplantation as Consolidation Therapy for Canine Lymphoma: Efficacy and Toxicity of Various Regimens of Total Body Irradiation. American Journal of Veterinary Research 1985;46(9) 2016-2018.

[252] Gasper PW, Rosen DK, Fulton R. Allogeneic Marrow Transplantation in a Cat with Acute Myeloid Leukemia. Journal of American Veterinary Medical Association 1996;208(8) 1280-1284.

[253] Frimberger AE, Moore AS, Rassnick KM, Cotter SM, O'Sullivan JL, Quesenberry PJ. A Combination Chemotherapy Protocol with Dose Intensification and Autologous Bone Marrow Transplant (VELCAP-HDC) for Canine Lymphoma. Journal of Veterinary Internal Medicine 2006;20(2) 355-364.

[254] Berenson JR, Lichtenstein A, Porter L, Dimopoulos MA, Bordoni R, George S, Lipton A, Keller A, Ballester O, Kovacs MJ, Blacklock HA, Bell R, Simeone J, Reitsma DJ, Heffernan M, Seaman J, Knight RD. Efficacy of Pamidronate in Reducing Skeletal Events in Patients with Advances Multiple Myeloma. New England Journal of Medicine 1996;334 488-493.

[255] Berenson JR, Hillner BE, Kyle RA, Anderson K, Lipton A, Yee GC, Biermann JS. American Society of Clinical Oncology-Clinical Practice Guidelines: The Role of Bisphosphonates in Multiple Myeloma. Journal of Clinical Oncology 2002;20(17) 3719-3736. 
[256] Berenson JR, Lichtenstein A, Porter L, Dimopoulos MA, Bordoni R, George S, Lipton A, Keller A, Ballester O, Kovacs M, Blacklock H, Bell R, Simeone JF, Reitsma DJ, Heffernan M, Seaman J, Knight RD. Long-Term Pamidronate Treatment of Advances Multiple Myeloma Patients Reduces Skeletal Events. Journal of Clinical Oncology 2008;16(2) 593-602.

[257] Body JJ, Bartl R, Burckhardt P, Delmas PD, Diel IJ, Fleisch H, Kanis JA, Kyle RA, Mundy GR, Paterson AH, Ruben RD. Current Use of Bisphosphonates in Oncology. Journal of Clinical Oncology 1998;16(12) 3890-3899.

[258] Fan TM. Intravenous Aminobisphosphonates for Managing Complications of Malignant Osteolysis in Companion Animals. Topics in Companion Animal Medicine 2009;24(3) 151-156.

[259] Fan TM, Charney SC, De Lorimier LP, Garrett LD, Griffon DJ, Gordon-Evans WJ, Wypij JM. Double-Blind Placebo-Controlled Trial of Adjuvant Pamidronate with Palliative Radiotherapy and Intravenous Doxorubicin for Canine Appendicular Osteosarcoma Bone Pain. Journal of Veterinary Internal Medicine 2009;23(1) 152-160.

[260] Hafeman SD, Varland D, Dow SW. Bisphosphonates Significantly Increase the Activity of Doxorubicin or Vincristine against Canine Malignant Histiocytosis Cells. Veterinary Comparative Oncology 2012;10(1) 44-56.

[261] Ural AU, Avcu F. Bisphosphonates may Potentate Effects of Thalidomide-Dexamethasone Combination in Advances Multiple Myeloma. American Journal of Hematology 2006;81(5) 385-386.

[262] Morgan GJ, Davies FE, Gregory WM, Szubert AJ, Bell SE, Drayson MT, Owen RG, Ashcroft AJ, Jackson GH, Child JA. Effects of Induction and Maintenance plus LongTerm Bisphosphonates on Bone Disease in Patients with Multiple Myeloma: The Medical Research Council Myeloma IX Trial. Blood 2012;119(23) 5374-5383.

[263] Moehler T, Goldschmidt H. Therapy of Relapsed and Refractory Multiple Myeloma. Recent Results in Cancer Research 2011;183 239-171.

[264] Ahn JS, Yang DH, Jung SH, Park HC, Moon JH, Sohn SK, Bae SY, Kim YK, Kim HJ, Lee JJ. A Comparison of Bortezomib, Cyclophosphamide, and Dexamethasone (VelCD) Chemotherapy without and with Thalidomide (Vel-CTD) for the Treatment of Relapsed or Refractory Multiple Myeloma. Annales of Hematology 2012;91(7) 1023-1030.

[265] Offidani M, Polloni C, Cavallo F, Liberati MA, Ballanti S, Pulini S, Catarini M, Alesiani F, Corvatta L, Gentili S, Caraffa P, Boccadoro M, Leoni P, Palumbo A. Phase II Study of Melphalan, Thalidomide and Prednisone Combined with Oral Panobinostat in Patients with Relapsed/Refractory Multiple Myeloma. Leukemia and Lymphoma 2012;53(9) 1722-1727.

[266] Hideshima T, Richardson P, Chauhan D, Palombello VJ, Elliot PJ, Adams J, Anderson KC. The Proteasome Inhibitor PS-341 Inhibits Growth, Induces Apoptosis, and Over- 
comes Drug Resistance in Human Multiple Myeloma. Cancer Research 2001;61 3071-3077.

[267] Drazner TH. Multiple Myeloma in the Cat. Compendium on Continuing Education for the Veterinary Practitioner 1982;4 206-216.

[268] Hawkins EC, Feldman BF, Blanchard PC. Immunoglobulin A Myeloma in a Cat with Pleural Effusion and Serum Hyperviscosity. Journal of American Veterinary Medical Association 1986;188 876-878. 